\title{
Phyllanthus muellerianus and Ficus exasperata exhibit anti-proliferative and pro-apoptotic activities in human prostate cancer PC-3 cells by modulating calcium influx and activating caspases
}

\section{Patrick Brice Defo Deeh ( $\nabla$ deehdefo@yahoo.fr)}

University of Dschang https://orcid.org/0000-0001-9865-4923

Madankumar Arumugam

Sathyabama Institute of Science and Technology

Karthik Alagarsamy

Sathyabama Institute of Science and Technology

Gayathri Karanam

Sathyabama Institute of Science and Technology

Nagabhishek Sirpu Natesh

Sathyabama Institute of Science and Technology

Pierre Watcho

University of Dschang

Vinita Vishwakarma

Sathyabama Institute of Science and Technology

\section{Research Article}

Keywords: P. muellerianus, F. exasperata, prostate cancer, apoptosis, PC-3 cells

Posted Date: December 17th, 2021

DOI: https://doi.org/10.21203/rs.3.rs-1063694/v1

License: (c) (1) This work is licensed under a Creative Commons Attribution 4.0 International License. Read Full License

Version of Record: A version of this preprint was published at Biologia on March 24th, 2022. See the published version at https://doi.org/10.1007/s11756-022-01065-z. 


\section{Abstract \\ Purpose}

Phyllanthus muellerianus (PM) and Ficus exasperata (FE) are plants used against cancers. We evaluated the phytochemical profiles and in vitro antioxidant potentials of PM and FE, and investigate their effects on cell proliferation, intracellular calcium $\left(\left[\mathrm{Ca}^{2+}\right]_{\mathrm{i}}\right.$ ), caspases $3 / 9$, apoptosis, oxidative stress markers, and Bax/cytochrome $\mathrm{C}$ expression in PC-3 cells.

\section{Methods}

The phytochemical profiles were evaluated by liquid chromatography-mass spectrometry (LC-MS), and the antioxidant by 2,2-diphenyl-1-picrylhydrazyl (DPPH) radicals scavenging method. The cells were incubated for 24 hours with $3 \%$ tween 80 , paclitaxel $(5 \mathrm{nM}), \mathrm{PM}(800$ and $1200 \mu \mathrm{g} / \mathrm{ml})$, and FE (800 and $1200 \mu \mathrm{g} / \mathrm{ml}$ ). After treatments, $\left[\mathrm{Ca}^{2+}\right]_{\mathrm{i}}$, caspases $3 / 9$, apoptosis and oxidative stress parameters were measured using colorimetric kits, while the mRNA levels of Bax and cytochrome $\mathrm{C}$ were quantified by RTqPCR.

\section{Results}

Nitidine, phloridzin and linoleic acid were identified in PM, while docosane, cardanol and chlorogenic acid were revealed in FE. The in vitro antioxidant potential of PM was greater than that of FE. Both plants inhibited the growth of PC-3 cells in a dose-dependent manner, but significantly $(p<0.5-0.001)$ increased $\left[\mathrm{Ca}^{2+}\right]_{\mathrm{i}}$, apoptosis level, caspase $3 / 9$ activities, reactive oxygen species production and lipid peroxidation, compared with control. Moreover, the activities of superoxide dismutase, catalase and glutathione peroxidase were significantly decreased in the cells incubated with the plant extracts, PM being the most effective. Paclitaxel, PM and FE upregulated Bax and cytochrome $C$ genes in PC-3 cells.

\section{Conclusion}

PM and FE inhibited the growth of PC-3 cells by modulating the $\left[\mathrm{Ca}^{2+}\right]_{i}$ and inducing apoptosis through Bax/Cytochrome C/Caspase 3-9 signaling pathway.

\section{Introduction}

Prostate cancer is a heterogeneous disease considered as the second leading cause of cancer-related deaths in men worldwide (Rawla 2019). The measurement of prostate-specific antigen (PSA), needle biopsy, transrectal ultrasound procedure, transrectal magnetic resonance imaging and digital rectal 
examinations are commonly used to detect and localize the disease before treatment (Litwin and Tan HJ 2017; Schoots and Padhani 2020; Yang et al. 2021).

The treatment of prostate cancer is based on the stage of the disease. For instance, surgery and radiation are commonly used when the disease is localized while chemotherapy is required for metastatic disease (Litwin and Tan HJ 2017; Wisniewski et al. 2020). Chemotherapeutic agents such as paclitaxel, docetaxel, and epothilones are clinically used in the management of prostate cancer (Wang et al. 2000). Given the complexity of this disease, the modern treatment is expensive and often associated with various side effects when the drugs are taken for a long time (Asay et al. 2020). Therefore, the search for an effective and safe alternative treatment is highly needed. Previous works demonstrated the efficacy of various plants against the proliferation and invasion of prostate cancer cells. For instance, Phyllanthus species (P. urinaria, P. niruri, P. watsonii and P. amarus) (Tang et al. 2010; 2015), Ficus microcarpa (Akhtar et al. 2018), Ficus deltoidea (Hanafi et al. 2017) and Ficus carica (Rubnov et al. 2001) decrease the growth of prostate cells. Phyllanthus muellerianus and Ficus exasperata also possess a wide range of pharmacological properties.

P. muellerianus (Euphorbiaceae) is a tropical plant called "Mbolongo" in Cameroon, and traditionally used to treat many ailments such as hepatitis B and C, diabetes, infertility, gastric ulcers and cancers (Rajeshkumar et al. 2002). Many phytocomponents such as caffeic acid, chlorogenic acid, gallic acid, ellagic acid and methyl gallate have been identified in this plant (Agyare et al. 2011). Tang et al. (2010) demonstrated that $P$. urinaria, $P$. niruri, $P$. watsonii and $P$. amarus inhibit the growth of PC-3 and MeWo cells by modulating cell cycle and inducing apoptosis. In addition, these Phyllanthus species also prevent tumor metastasis and angiogenesis in PC-3 and MeWo cells (Tang et al. 2015). The mixture of Phyllanthus amarus and Paramignya trimera has shown a dose dependent anti-proliferative potential in Du145, A2780 and MCF-7 cells (Nguyen et al. 2021). We previously demonstrated that $P$. muellerianus prevents the proliferation of ovarian cysts and improves reproductive potential of rats with polycystic ovary syndrome (Ndeingang et al. 2019), but the effect of this plant on PC-3 cells is unknown.

F. exasperata (Moraceae), commonly known as sandpaper is a tropical plant widely used to treat many diseases such as arthritis, hypertension, infertility, gastric disorders and cancers (Faiyaz et al. 2012; Adekeye et al. 2020). Phytochemical analysis of different parts (barks, leaves and fruits) of $F$. exasperata revealed the presence of many compounds including cinnamoyl derivatives (caffeic acid, caffeoylquinic acid, malic acid, ferulic acid and sinapic acid), flavonoid-0-glycosides (isoquercitrin, kaempferol and rhamnosyl), flavonoid-mono-C-glycosides (apigenin-8-C-glucoside, ketorhamnosyl and apigenin) flavonoid-di-C-glycosides (luteolin-6,8-di-C-hexoside and apigenin-C-deoxyhexoside-C-hexoside), and furanocoumarins (bergapten and oxypeucedanin hydrate) (Mouho et al. 2018; Mikail et al. 2019). Moreover, seven organic acids (oxalic, aconitic, citric, tartaric, malic, quinic, fumaric) were also identified in F. exasperata extacts (Mouho et al. 2018). The in vitro antioxidant potential (Akanni et al. 2014) and antiproliferative activities of $F$. exasperata have been reported in ovarian cancer cells (Bafor et al. 2017). 
Although Tang et al. (2010; 2015) and Bafor et al. (2017) have reported the beneficial effects of some Phyllanthus sp and F. exasperata, respectively on MeWo prostate cancer and A2780 ovarian cancer cells, their effects on PC-3 cells have not been investigated. We characterized $P$. muellerianus and $F$. exasperata extracts by LC-MS analysis and determined their in vitro antioxidant potentials by DPPH assay. With the hypothesis that the phytocomponents revealed in these plants may prevent prostate cancer, we evaluated the effects $P$. muellerianus and $F$. exasperata on cell proliferation, $\left[\mathrm{Ca}^{2+}\right]_{\mathrm{i}}$, apoptosis level, ROS production, caspase $3 / 9$ activities, lipid peroxidation, antioxidant enzymes (SOD, CAT and GSH-Px) and mRNA levels of Bax and cytochrome $\mathrm{C}$ in PC-3 cells.

\section{Materials And Methods}

\section{Collection of $P$. muellerianus and $F$. exasperata}

P. muellerianus roots and the stem barks of $F$. exasperata were harvested in April 2017 in Tonga (West Cameroon). The plants were identified at the Cameroon National Herbarium (CNH) under the voucher number $\mathrm{N}^{\circ}$ BWPV03 (for $P$. muellerianus) and $\mathrm{N}^{\circ}$ 56091/HNC (for $F$. exasperata). The roots and stem barks were separately shade-dried for 7 days, later transformed into powder and used for preparation of the methanolic extracts of $P$. muellerianus and $F$. exasperata.

\section{Preparation of methanolic extracts of $P$. muellerianus and $F$. exasperata}

$250 \mathrm{~g}$ of $P$. muellerianus powder were macerated in methanol $(1000 \mathrm{ml})$ for 72 hours and filtered using Whatman no. 1 filter paper. The filtrate was evaporated using a rotary evaporator and $15.17 \mathrm{~g}$ of methanolic extract was obtained (extraction yield: 6.07\%) (Ndeingang et al. 2019).

F. exasperata powder $(250 \mathrm{~g})$ was macerated in methanol $(1000 \mathrm{ml})$ for 72 hours and filtered. The filtrate was evaporated (using a rotary evaporator) and $26.43 \mathrm{~g}$ of methanolic extract was obtained (extraction yield: $10.57 \%)$.

\section{LC-MS analysis of $P$. muellerianus and $F$. exasperata extracts}

P. muellerianus and F. exasperata were analyzed as described previously (Deeh et al. 2018). Briefly, after connection of the spectrometer to an Ultimate 3000 UHPLC system, the separations were done by a Synergi MAX-RP 100A, with a $\mathrm{H}_{2} \mathrm{O}(+0.1 \% \mathrm{HCOOH})(\mathrm{A}) /$ acetonitrile $(+0.1 \% \mathrm{HCOOH})(B)$ gradient (flow rate $500 \mu \mathrm{L} / \mathrm{min}$, injection volume $10 \mu \mathrm{l})$. Samples were analyzed and identification of phyto-constituents present in $P$. muellerianus and $F$. exasperata extracts was based on the information from the spectra and data present in the literature (Oboh et al. 2014; Kumar et al. 2015; Elsawi et al. 2020).

\section{Evaluation of in vitro antioxidant potential of $P$. muellerianus and $F$. exasperata by DPPH assay}

The antioxidant potentials of $P$. muellerianus, F. exasperata and ascorbic acid (positive control) were evaluated via their scavenging activity against 2,2-diphenyl-1-picrylhydrazyl (DPPH) radical as reported by Koleva et al. (2002) with minor modifications. $10 \mu \mathrm{L}$ of each concentration (400, 800, 1200 and 2000 
$\mu \mathrm{g} / \mathrm{ml})$ of $P$. muellerianus or $F$. exasperata was added to DPPH $(190 \mu \mathrm{L} ; 150 \mu \mathrm{M})$ in ethanol solution. The absorbance was recorded at $517 \mathrm{~nm}$ and the percentage of inhibition was estimated (Karanam et al. 2020).

\section{Cell culture}

The PC-3 human prostate cancer cell line was purchased from the National Centre for Cell Science, NCCS, Pune, India. They were cultured in $5 \% \mathrm{CO}_{2}$ and $95 \%$ air in RPMI medium supplemented with $10 \% \mathrm{FBS}$ and $1 \%$ penicillin-streptomycin at $37^{\circ} \mathrm{C}$ in a humidified incubator. The cell culture was done in an aseptic condition and the medium was changed every alternative days to avoid contamination. Every week, the cultures were split into different flasks after the cells reached at $80 \%$ confluence.

\section{Measurement of cell viability and treatments}

The effects of plant extracts on the viability of PC-3 cells were investigated by using 3-(4,5-dimethylthiazol-2-yl)-2,5-diphenyltetrazolium bromide (MTT) assay (Övey et al. 2015; Deeh et al. 2018; Nazıroğlu et al. 2019). Briefly, the cells were seeded in 96-well plates (1.5 x $10^{4}$ cells/well). After the cells reached good growth, cells were incubated for 24 hours with the vehicle or various concentrations $(400,800,1200$ and $2000 \mu \mathrm{g} / \mathrm{ml})$ of plant extracts. In each well, $200 \mu \mathrm{l}$ of MTT ( $5 \mathrm{mg} / \mathrm{ml}$ : $1 \mathrm{X}$ PBS) was added and incubated for $2 \mathrm{~h}$. DMSO $(200 \mu \mathrm{l})$ was added in each well and absorbance was recorded at $650 \mathrm{~nm}$ using Perkin Elmer multimode plate reader. All experiments were carried out in triplicates. Two moderate doses (infra $\mathrm{IC}_{50}: 800 \mu \mathrm{g} / \mathrm{ml}$ and supra $\mathrm{IC}_{50}: 1200 \mu \mathrm{g} / \mathrm{ml}$ ) of plant extracts were selected and used for further studies.

Further, the cells were treated as follows: (1) control group: cells were kept in a flack without any drug; (2): tween 80: cells were incubated with $3 \%$ tween 80; (3): paclitaxel: cells were treated with paclitaxel at 5 $\mathrm{nM}$; (4 and 5): F.e 800 and $1200 \mu \mathrm{g} / \mathrm{ml}$ : cells were incubated with the methanolic extract of $F$. exasperata at 800 and $1200 \mu \mathrm{g} / \mathrm{ml}$, respectively; (6 and 7): P.m 800 and $1200 \mu \mathrm{g} / \mathrm{ml}$ : cells were treated with the methanolic extract of $P$. muellerianus at 800 and $1200 \mu \mathrm{g} / \mathrm{ml}$, respectively. The methanolic extracts of $F$. exasperata and $P$. muellerianus were dissolved in $3 \%$ tween 80 before treatments. The dose of paclitaxel ( $5 \mathrm{nM}$ ) was chosen in a previous study (Zhang et al. 2020). At the end of the incubation period (24 hours), intracellular calcium concentration $\left(\left[\mathrm{Ca}^{2+}\right]_{i}\right)$, apoptosis level, caspase $3 / 9$ activities, oxidative stress-related markers (ROS, MDA, SOD, CAT and GSH-Px) and mRNA levels of Bax and cytochrome $\mathrm{C}$ were measured.

\section{Determination of $\left[\mathrm{Ca}^{2+}\right]_{\mathrm{i}}$}

The $\left[\mathrm{Ca}^{2+}\right]_{i}$ was estimated using fura-2 acetoxymethyl ester (Fura-2/AM) as described previously (Deeh et al. 2018; Gökçe et al. 2019). Briefly, after treatment with the vehicle or drugs, the cells were loaded with $4 \mu \mathrm{M}$ fura-2/AM in the dark for $45 \mathrm{~min}$ and washed three times with phosphate buffer. The cells were incubated for an additional $30 \mathrm{~min}$ and re-suspended in loading buffer. All cells incubated with the vehicle 
or drugs were treated with $\mathrm{H}_{2} \mathrm{O}_{2}$ to stimulate $\left[\mathrm{Ca}^{2+}\right]_{\mathrm{i}}$ release and the fluorescence was recorded using a spectrofluorometer. $\left[\mathrm{Ca}^{2+}\right]_{\mathrm{i}}$ was estimated as described earlier (Grynkiewicz et al. 1985; Nazıroğlu et al. 2019).

\section{Measurement of apoptosis level and caspase $3 / 9$ activities}

After treatment ( 24 hours) with the vehicle or drugs, the apoptosis assay was conducted using a colorimetric kit (Biocolor Ltd, Northern Ireland) following the manufacturer's instructions as described earlier (Özdemir et al. 2016). The determination of caspases $3 / 9$ activities was done by fluorescence microscopy as previously described (Espino et al. 2010; Nazıroğlu et al. 2019). The results were expressed as fold increase over the pretreatment level (experimental/control).

\section{Evaluation of ROS, lipid peroxidation, SOD, CAT and GSH-Px levels}

ROS production was estimated using dihydrorhodamine-123 (DRH 123) as described previously (Joshi et al. 2011; Keil et al. 2011). Indeed, DRH 123 easily penetrates inside the cells and becomes fluorescent after oxidation. The intensity of fluorescence is proportional to ROS accumulation. In all samples, the intensity of fluorescence was recorded at $488 \mathrm{~nm}$ (excitation) and $543 \mathrm{~nm}$ (emission) using a professional micro plate reader (Infinite pro200).

The activities of SOD and catalase were measured as described by Shiraishi et al. (2005) and Sinha et al. (1984), respectively. Glutathione peroxidase (GSH-PX) activity and MDA level were measured using a detection kit according to the manufacturer's instructions.

\section{RNA extraction and quantitative real-time polymerase chain reaction}

RT-qPCR was performed to detect the expression level of Bax and Cytochrome $\mathrm{C}$ in PC-3 cells after treatment with the reference drug (paclitaxel) and $F$. exasperata and $P$. muellerianus extracts. The experimental conditions were the same as described previously (Olugbodi et al. 2019). Briefly, total RNA from the PC-3 cells was extracted using Qiagen RNeasy Mini Kit as defined according to the manufacturer protocol. Total RNA was reverse transcribed using the SuperScript1 VILOTM Kit and RTqPCR was performed with SsoAdvancedTM SYBR1 and a CFX96 TouchTM devices. Gene specific primers Bax forward 5'-TTGCTTCAGGGTTTCATCCA-3', Bax reverse 5'-CAGCCTTGAGCACCAGTTTG-3' and Cytochrome $C$ forward 5'-AGTGGCTAGAGTGGTCATTCATTTACA-3', Cytochrome $C$ reverse 5'TCATGATCTGAATTCTGGTGTATGAGA-3' were used for target gene amplification. To enumerate gene expression, the $\mathrm{Ct}$ of target gene amplification was regularised to the expression level of a housekeeping gene (GADPH forward 5'- AACTCAGGAGAGTGTTTCCTCG-3', GADPH reverse 5'-

TGATGGGCTTCCCGTTGATG-3'), based on the relation R = ECtRpl19/ECttarget, wherever $E$ is the magnification potency for every primer pair (Olugbodi et al. 2019).

\section{Statistical analysis}


Data were expressed as mean \pm SEM. Comparison between vehicle and drug groups was made by ANOVA one-way followed by the post hoc Tukey HSD test using STATISTICA software, version 8.0 (StatSoft, Inc., Tulsa, USA). Each experiment was repeated three times. Significance level was set at 0.05 or less.

\section{Results}

\section{LC-MS analysis}

The LC-MS chromatograms of the methanolic extracts of $P$. muellerianus (Figure 1 ) and $F$. exasperata (Figure 2) showed the peak areas for various components. The information from the spectra and data present in the literature allow tentative identification of nitidine (molecular weight $348.37 \mathrm{~g} / \mathrm{mol}$ ) at RT 1.26 min with $[\mathrm{M}+\mathrm{H}]+$ at $\mathrm{m} / \mathrm{z} 348$ (Figure $2 \mathrm{~A}$ and $\mathrm{B}$ ), phloridzin (molecular weight $436.4 \mathrm{~g} / \mathrm{mol}$ ) at RT 3.19 min with $[\mathrm{M}+\mathrm{H}]+$ at $\mathrm{m} / \mathrm{z} 435$ (Figure $2 \mathrm{~A}$ and $\mathrm{C}$ ) and linoleic acid (molecular weight $280.4472 \mathrm{~g} / \mathrm{mol}$ ) at RT 3.84 min with $[\mathrm{M}+\mathrm{H}]+$ at $\mathrm{m} / \mathrm{z} 279$ (Figure $2 \mathrm{~A}$ and $\mathrm{D}$ ) in the methanolic extract of $P$. muellerianus. In the methanolic extract of $F$. exasperata, docosane (molecular weight $310.6027 \mathrm{~g} / \mathrm{mol}$ ) at RT $2.42 \mathrm{~min}$ with $[\mathrm{M}+\mathrm{H}]+$ at $\mathrm{m} / \mathrm{z} 311$ (Figure $3 \mathrm{~A}$ and B), cardanol (molecular weight $298.5 \mathrm{~g} / \mathrm{mol}$ ) at RT $2.95 \mathrm{~min}$ with $[\mathrm{M}+\mathrm{H}]+$ at $\mathrm{m} / \mathrm{z} 297$ (Figure $3 \mathrm{~A}$ and $\mathrm{C}$ ) and chlorogenic acid (molecular weight $354.31 \mathrm{~g} / \mathrm{mol}$ ) at RT 4.42 min with $[\mathrm{M}+\mathrm{H}]+$ at $\mathrm{m} / \mathrm{z} 355$ (Figure $3 \mathrm{~A}$ and $\mathrm{D}$ ) were identified. Other phytocomponents from these plants were not identified in the current work.

\section{Assay of DPPH radical scavenging activity}

As shown in Figure 3, the DPPH scavenging activity of methanolic extracts from P. muellerianus and $F$. exasperata increased $(\mathrm{p}<0.001)$ in a dose-dependent manner, $P$. muellerianus being the most effective. Ascorbic acid significantly $(p<0.001)$ increased DPPH scavenging activity from 400 to 1200 $\mu \mathrm{g} / \mathrm{ml}$, but decreased $(\mathrm{p}<0.001)$ at the highest dose $(2000 \mu \mathrm{g} / \mathrm{ml})$ (Figure 3$)$.

\section{P. muellerianus and F. exasperata inhibited the growth of PC-3 cells}

The cell viability was significantly $(\mathrm{p}<0.05-0.001)$ decreased after treatment with $P$. muellerianus (Figure 4) and F. exasperata (Figure 5), compared to the control or tween 80 group. P. muellerianus was more effective (at all doses) in inhibiting the growth of PC-3 cells than F. exasperata (Figures 4 and 5).

\section{Paclitaxel, $P$. muellerianus and $F$. exasperata modulated the intracellular $\left[\mathrm{Ca}^{2+}\right]_{\mathrm{i}}$ in $\mathrm{PC}-3$ cells}

Paclitaxel, P. muellerianus and F. exasperata significantly increased the $\left[\mathrm{Ca}^{2+}\right]_{\mathrm{i}}$ in $\mathrm{PC}-3$ cells, compared to the control or tween 80 group. The effects of plant extracts were dose-dependent. The efficacy of $P$. muellerianus was higher than that of $F$. exasperata. However, paclitaxel was more powerful than plant extracts (Figure 6A and B).

Paclitaxel, P. muellerianus and F. exasperata promoted apoptosis, ROS production and caspase 3/9 activities in PC-3 cells 
As shown in Figure $7 \mathrm{~A}$ and $\mathrm{B}$, paclitaxel, P. muellerianus and F. exasperata significantly $(\mathrm{p}<0.05-$ 0.001 ) increased the apoptosis level and ROS production, compared to the control or tween 80 group. The effects of plant extracts were dose-dependent, P. muellerianus $(1200 \mu \mathrm{g} / \mathrm{ml})$ being the most effective.

Caspase $3 / 9$ activities were significantly $(\mathrm{p}<0.05-0.001)$ elevated in the cells incubated with paclitaxel, $P$. muellerianus and $F$. exasperata, compared to the control or tween 80 group. The efficacy of $P$. muellerianus was higher than that of F. exasperata (Figure $8 \mathrm{~A}$ and $\mathrm{B}$ ).

Overall, paclitaxel was more effective in initiating apoptosis by modulating the activation of caspases $3 / 9$ than plant extracts (Figure 7 and 8 ).

\section{Paclitaxel, $P$. muellerianus and $F$. exasperata increased lipid peroxidation and oxidative stress in PC-3 cells}

The level of MDA increased significantly $(\mathrm{p}<0.05-0.001)$ in the cells incubated with paclitaxel and plant extracts, with the highest effect observed in P. muellerianus $(1200 \mu \mathrm{g} / \mathrm{ml})$ group (Figure 9$)$.

The activities of SOD, CAT and GSH-Px were significantly $(p<0.05-0.001)$ decreased after treatment with paclitaxel, F. exasperata (except SOD: F.e $800 \mu \mathrm{g} / \mathrm{ml}$ group) or P. muellerianus, compared to the control or tween 80 group. $P$. muellerianus was more effective in modulating MDA and SOD activity while $F$. exasperata exhibited the highest effect on CAT and GSH-Px activities (Figure 10A-C).

\section{Paclitaxel, $P$. muellerianus and $F$. exasperata up-regulated mRNA expression of Bax and cytochrome $C$ in PC-3 cells}

Paclitaxel, P. muellerianus and $F$. exasperata significantly increased $(p<0.05)$ the mRNA levels of Bax and cytochrome $\mathrm{C}$ in $\mathrm{PC}-3$ cells, compared with control and tween 80 groups. The effects of plant extracts were dose-dependent. Paclitaxel was more effective than plant extracts (Figure 11).

\section{Discussion}

Natural products are effective and reliable sources for the development of anticancer drugs with slight or no side effects (Kasala et al. 2015). Numerous studies have indicated that Phyllanthus sp ( $P$. urinaria, $P$. niruri, P. watsonii and P. amarus) (Tang et al. 2010; 2015) and $F$. exasperata (Bafor et al. 2017), respectively inhibit the proliferation of MeWo prostate cancer and A2780 ovarian cancer cells, but there is no work on the effects of these tropical plants on the PC-3 prostate cancer cells. This work was planned to evaluate the effects $P$. muellerianus and $F$. exasperata on cell proliferation, intracellular calcium concentration $\left(\left[\mathrm{Ca}^{2+}\right]_{\mathrm{i}}\right)$, apoptosis level, caspase $3 / 9$ activities, oxidative stress related markers (ROS, MDA, SOD, CAT and GSH-Px) and mRNA levels of Bax and cytochrome $C$ in PC-3 cells. Our results herein demonstrated that $P$. muellerianus and $F$. exasperata possess potent antioxidant property in vitro and exhibit an anti-proliferative property on $\mathrm{PC}-3$ cells by modulating the $\left[\mathrm{Ca}^{2+}\right]_{\mathrm{i}}$ and inducing apoptosis through Bax/Cytochrome C/Caspase 3-9 signaling pathway. 
The DPPH assay is used to determine the capacity of a drug to scavenge free radicals (Abotsi et al. 2010). In this work, the DPPH scavenging activity assay of the methanolic extract of $P$. muellerianus significantly increased in a dose-dependent manner, as reported by Boakye et al. (2016). This antioxidant potential could be due to the presence of the components which has the ability to quench free radicals. Indeed, in the current study, LC-MS chromatograms of $P$. muellerianus revealed the presence of nitidine, phloridzin and linoleic acid. The antioxidant properties of nitidine (Chen et al. 2012), phloridzin (Rezk et al. 2002) and linoleic acid (Fagali and Catalá 2008; Xu et al. 2020) were reported previously. We also found that the in vitro antioxidant activity of $F$. exasperata was lower than that of $P$. muellerianus. The antioxidant potential of $F$. exasperata could be due to the presence of antioxidant components such as docosane, cardanol and chlorogenic acid. Even low doses $(30-300 \mu \mathrm{g} / \mathrm{ml})$ of $F$. exasperata possess a strong DPPH scavenging activity (Abotsi et al. 2010). However, ascorbic acid used as a positive control increased the DPPH scavenging activity at low $(400 \mu \mathrm{g} / \mathrm{ml})$ or moderate $(800$ and $1200 \mu \mathrm{g} / \mathrm{ml})$ dose, but decreased at high concentration $(2000 \mu \mathrm{g} / \mathrm{ml})$. This reduction in the antioxidant potential of ascorbic acid at high dose could be due to its toxicity (Eylar et al. 1996).

P. muellerianus and F. exasperata significantly decreased the viability of PC-3 cells (in a dose-dependent manner) compared with control. The capacity of $P$. muellerianus to decrease the growth of PC-3 cells corroborated the work of Tang et al. (2010) who reported that other Phyllanthus sp ( $P$. urinaria, $P$. niruri, $P$. watsonii and $P$. amarus) inhibit the proliferation of PC-3 cells via the modulation of cell cycle and induction of apoptosis through MAPKs, PI3K/Akt, NFB, and hypoxia pathways. The anti-proliferative potential of $P$. muellerianus could be attributed to the presence of various phyto-components such as nitidine, phloridzin and linoleic acid. It has been shown that nitidine exhibited preferential cytotoxic activity against the growth of human gastric cancer cells by inhibiting STAT3 signaling pathway (Chen et al. 2012). Phloridzin (Choi 2019) and linoleic acid (Lu et al. 2010) are known to suppress tumor growth by inducing oxidant stress, blocking cyclin-dependent kinases and inducing apoptosis. However, the antiproliferative effect of $F$. exasperata observed in the current study was previously reported on ovarian cancer cells (Bafor et al. 2017), which may be due to its contain in docosane, cardanol and chlorogenic acid. The anti-proliferative potentials of $P$. muellerianus and $F$. exasperata could be associated to their ability to modulate calcium influx in the cells.

$\mathrm{Ca}^{2+}$ is a second messenger involved in the regulation of cellular function (Romero-Garcia and PradoGarcia 2019). In a pathological condition, abnormal $\mathrm{Ca}^{2+}$ concentration inside and outside of cell activates receptor dependent signals and promotes the production of pro-apoptotic markers, such as cytochrome c, leading to apoptosis (Bardak et al. 2017). In the present work, P. muellerianus and $F$. exasperata significantly increased the $\left[\mathrm{Ca}^{2+}\right]_{i}$ and apoptosis level in the PC-3 cells, $P$. muellerianus being the most effective. In parallel, Phyllanthus amarus promotes apoptosis in cervical cancer cells by activating p53 and p21 (Paul et al. 2019). Wu et al. (2012) reported the pro-apoptotic potential of Phyllanthus urinaria against human osteosarcoma cancer cells through activation of Fas receptor/ligand. On the other hand, the pro-apoptotic properties of $F$. exasperata have been demonstrated in various cells including A2780 ovarian cancer cells (Bafor et al. 2017). The enhancing effects of $P$. 
muellerianus and $F$. exasperata on $\left[\mathrm{Ca}^{2+}\right]_{i}$ and apoptosis could be associate to their contain in proapoptotic phyto-components. For instance nitidine (identified in the methanolic extract of $P$. muellerianus) is a compound with a powerful pro-apoptotic potential via activation of Checkpoint kinase 2 (Chk2) in human cervical cancer cells (Kwon et al. 2019). Moreover, cardanol revealed in F. exasperata is capable to activate apoptosis in M14 melanoma cells by up-regulating p53, cytochrome C, cleaved-caspase-3 and cleaved-PARP (Su et al. 2017). The high $\left[\mathrm{Ca}^{2+}\right]_{i}$ and apoptosis level observed in the cells incubated with paclitaxel is evident, because it is a reference drug used in the treatment of various cancers including lung cancer, ovarian cancer, breast cancer, and prostate cancer (Zhu and Chen 2019). Indeed, it has been reported that the beneficial effects of paclitaxel is due to its ability to induce cell death by mobilizing extracellular calcium influx and promoting apoptosis through kinetic suppression of microtubule dynamics (Wang et al. 2000).

Although calcium signaling is an important factor of triggering the apoptosis, caspase pathways and ROS are also involved (Simon et al. 2000). Under both normal and pathologic conditions, ROS induces apoptosis by increasing the extracellular calcium and up-regulating caspase genes (Simon et al. 2000). The overproduction of ROS also causes DNA damage and negatively affects the integrity of chromosomes, associated with the activation of pro-apoptotic markers, leading to cancer cell death (Görlach et al. 2015). In the present study, P. muellerianus and F. exasperata promoted caspase 3/9 activities and ROS generation in the PC-3 cells. Similarly, other Phyllanthus $\mathrm{sp}(P$. urinaria, $P$. niruri, $P$. watsonii and $P$. amarus) facilitate caspases activation and increase apoptosis in PC-3 and MeWo human cancer cells (Tang et al. 2010). Although no in vitro study on the effects of $F$. exasperata on ROS and caspase levels has been found in the literature, this plant has significant antiproliferative and cytotoxic properties in ovarian cancer cells (Bafor et al. 2017).

The induction of oxidative stress is an important mechanism of some anticancer drugs (Wang et al. 2000). We found in the current study that paclitaxel, $P$. muellerianus and $F$. exasperata induced oxidative stress in the PC-3 cells by significantly increasing MDA level and lowering antioxidant enzymes (SOD, TAC and GPx). The capacity of plant extracts to increase oxidative stress in PC-3 cells may be due to their stimulatory effects on the activity of xanthine oxidase (as free radicals activator). In parallel, Astaxanthin (a carotenoid compound used as dietary supplement) significantly lowered the activities of SOD, CAT and GSH-Px in the PC-3 prostate cancer cells, but had an opposite effect in the RWPE-1 prostate normal cells (Görlach et al. 2015). Thus the effects of $P$. muellerianus and $F$. exasperata on normal prostate cells are highly needed.

Bax and cytochrome $\mathrm{C}$ are pro-apoptotic factors. In the intrinsic partway of apoptosis, movement of Bax into the mitochondria leads to the release of cytochrome $C$ which activates the caspase machineries, leading to apoptosis (Green 2006; Imran et al. 2020). The significant increase in the mRNA levels of Bax and cytochrome $\mathrm{C}$ in PC-3 cells incubated with Paclitaxel, $P$. muellerianus and $F$. exasperata indicated that their pro-apoptotic properties is due to the activation of Bax/cytochrome $\mathrm{C} /$ caspase partway. To the best of our knowledge, the current work is the first to illustrate the role of $F$. exasperata and $P$. muellerianus on the proliferation of PC-3 cells. Based on the data obtained, it could be proposed that $F$. exasperata and $P$. 
muellerianus could act by activating caspase 8 and increasing calcium influx and ROS production, leading to oxidative stress. This may up-regulate Bax proteins and increase cytochrome $\mathrm{C}$ release by the mitochondria. In this condition, cytochrome $\mathrm{C}$ (a pro apoptotic factor) could activate caspase 3/9 machineries and apoptosis pathways, which may ultimately modulate PC-3 proliferation (Figure 12). However, more molecular works are highly needed to further clarify this mechanism.

\section{Conclusion}

P. muellerianus and F. exasperata are potent anti-oxidative plants with strong radical scavenging activity. These plants exhibited an anti-proliferative property on PC-3 cells by modulating the $\left[\mathrm{Ca}^{2+}\right]_{\text {, }}$, and inducing apoptosis through Bax/Cytochrome C/Caspase 3-9 signaling pathway. P. muellerianus and $F$. exasperata may be sourced for the development of an effective therapeutic drug for the management of prostate cancer.

\section{Declarations}

\section{Ethics approval}

Not applicable

\section{Consent to participate}

Not applicable

\section{Consent to publish}

Not applicable

\section{Authors' contributions}

PBDD and VV participated in the study conception and conducted the experimental research. PBDD, MA, $\mathrm{KA}$ and

GK participated in the data interpretation, data analysis and statistical analysis for the variables. PBDD, NSN, PW and VV drafted the paper. PBDD and VV were responsible for the overall supervision. All coauthors read and approved the final manuscript. The authors declare that all data were generated inhouse and that no paper mill was used.

\section{Funding}

This work was supported by CV Raman (Ref: INT/NAI/CVRF/2016) and Sathyabama Institute of Science and Technology, Chennai, India.

\section{Conflict of interest}


The authors declare no conflict of interest.

\section{Data Availability}

All relevant data can be provided upon request.

\section{Availability of data and materials}

Supplementary materials are available.

\section{References}

Abotsi WMK, Woode E, Ainooson GK, Amo-Barimah AK, Boakye-Gyasi E (2010) Antiarthritic and antioxidant effects of the leaf extract of Ficus exasperata P. Beauv. (Moraceae). Pharmacognosy Res 2:89-97. https://www.ncbi.nlm.nih.gov/pmc/articles/PMC3140113/

Adekeye AO, Irawo GJ, Fafure AA (2020) Ficus exasperata Vahl leaves extract attenuates motor deficit in vanadium-induced parkinsonism mice. Anat Cell Biol 53:183-

193. https://www.ncbi.nlm.nih.gov/pmc/articles/PMC7343565/

Agyare C, Lechtenberg M, Deters A, Petereit F, Hensel A (2011) Ellagitannins from Phyllanthus muellerianus (Kuntze) Exell.: Geraniin and furosin stimulate cellular activity, differentiation and collagen synthesis of human skin keratinocytes and dermal fibroblasts. Phytomedicine 18:617624. https://doi.org/10.1016/j.phymed.2010.08.020

Akanni OO, Owumi SE, Adaramoye OA (2014) In vitro studies to assess the antioxidative, radical scavenging and arginase inhibitory potentials of extracts from Artocarpus altilis, Ficus exasperata and Kigelia africana. Asian Pac J Trop Biomed 4:S492-

9. https://www.ncbi.nlm.nih.gov/pmc/articles/PMC4025265/

Akhtar N, Syed DN, Lall RK, Mirza B, Mukhtar H (2018) Targeting epithelial to mesenchymal transition in prostate cancer by a novel compound, plectranthoic acid, isolated from Ficus microcarpa. Mol Carcinog 57: 653-663. https://doi.org/10.1002/mc.22790

Asay S, Graham A, Hollingsworth S, Barnes B, Oblad RV, Michaelis DJ, et al (2020) $\gamma$-Tocotrienol and aTocopherol ether acetate enhance docetaxel activity in drug-resistant prostate cancer cells. Molecules 25:398. https://doi.org/10.3390/molecules25020398

Bafor EE, McKenna J, Rowan EG, Edrada-Ebel R (2017) Characterisation of the antiproliferative constituents and activity of Ficus exasperata (Vahl) on ovarian cancer cells - a preliminary investigation. Nat Prod Res 31:2164-2168. https://doi.org/10.1080/14786419.2016.1277348

Bardak H, Uğuz AC, Bardak Y (2017) Curcumin regulates intracellular calcium release and inhibits oxidative stress parameters, VEGF, and caspase-3/-9 levels in human retinal pigment epithelium cells. 
Physiol Int 104:301-315. https://doi.org/10.1556/2060.104.2017.4.3

Boakye YD, Agyare C, Dapaah SO (2016) In vitro and in vivo antioxidant properties of Phyllanthus muellerianus and its major constituent, geraniin. Oxid Antioxid Med Sci 5:7078. http://ir.knust.edu.gh/xmlui/handle/123456789/11236

Chen J, Wang J, Lin L, He L, Wu Y, Zhang L, et al (2012) Inhibition of STAT3 signaling pathway by nitidine chloride suppressed the angiogenesis and growth of human gastric cancer. Mol Cancer Ther 11:27787. https://doi.org/10.1158/1535-7163.mct-11-0648

Choi BY (2019) Biochemical basis of anti-cancer-effects of phloretin-a natural dihydrochalcone. Molecules 24(2):278. https://doi.org/10.3390/molecules24020278

Deeh DPB, Watcho P, Wankeu-Nya M, Ngadjui E, Usman UZ (2018) The methanol extract of Guibourtia tessmannii (caesalpiniaceae) and selenium modulate cytosolic calcium accumulation, apoptosis and oxidative stress in R2C tumour Leydig cells: Involvement of TRPV1 channels.

Andrologia 51:e13216. https://doi.org/10.1111/and.13216

Elsawi SA, Radwan RR, Elbatanony MM, El-Feky AM, Sherif NH (2020) Prophylactic effect of Opuntia ficus indica fruit peel extract against irradiation-induced colon injury in rats. Planta Med 86:6169. https://doi.org/10.1055/a-1019-9801

Espino J, Bejarano I, Redondo PC, Rosado JA, Barriga C, Reiter RJ, et al (2010) Melatonin reduces apoptosis induced by calcium signaling in human leukocytes: evidence for the involvement of mitochondria and Bax activation. J Membr Biol 233:105-118. https://doi.org/10.1007/s00232-010-92300

Eylar E, Báez I, Navas J, Mercado, C (1996) Sustained levels of ascorbic acid are toxic and immunosuppressive for human T cells. P R Health Sci J 15:21-

6. https://pubmed.ncbi.nlm.nih.gov/8744863/

Fagali N, Catalá A (2008) Antioxidant activity of conjugated linoleic acid isomers, linoleic acid and its methyl ester determined by photoemission and DPPH techniques. Biophys Chem 137:5662. https://doi.org/10.1016/j.bpc.2008.07.001

Faiyaz A, Mueen-Ahmed KK, Zainul-Abedin MD, Alias A, Karim AA (2012) Traditional uses and pharmacological potential of Ficus exasperata Vahl. Syst. Rev. Pharm 3:15-

23. https://www.sysrevpharm.org/abstract/traditional-uses-and-pharmacological-potential-of-ficusexasperata-vahl-64921.html

Gökçe KS, Gökçe G, Kütük M, Gürses CHE, Nazıroğlu M (2019) Curcumin enhances cisplatin-induced human laryngeal squamous cancer cell death through activation of TRPM2 channel and mitochondrial oxidative stress. Sci Rep. 9:17784. https://doi.org/10.1038/s41598-019-54284-x 
Görlach A, Bertram K, Hudecova S, Krizanova $O$ (2015) Calcium and ROS: A mutual interplay. Redox Biol 6:260-271. https://doi.org/10.1016/j.redox.2015.08.010

Green DR (2006) At the gates of death. Cancer Cell. 9:328330. https://doi.org/10.1016/j.ccr.2006.05.004

Grynkiewicz C, Poenie M, Tsien, RY (1985) A new generation of $\mathrm{Ca}^{2+}$ indicators with greatly improved fluorescence properties. J Biol Chem 260:3440-3450. https://www.jbc.org/article/S0021-9258(19)83641$4 / p d f$

Hanafi MMM, Afzan A, Yaakob H, Aziz R, Sarmidi MR, Wolfender JL, et al (2017) In vitro pro-apoptotic and anti-migratory effects of Ficus deltoidea L. Plant extracts on the human prostate cancer cell lines PC3. Front Pharmacol 8:895. https://doi.org/10.3389/fphar.2017.00895

Imran M, Aslam-Gondal T, Atif M, Shahbaz M, Batool-Qaisarani T, Hanif-Mughal M, et al (2020) Apigenin as an anticancer agent. Phytother Res 34:1812-1828. https://doi.org/10.1002/ptr.6647

Joshi DC, Bakowska JC (2011) Determination of mitochondrial membrane potential and reactive oxygen species in live rat cortical neurons. J Vis Exp 51:2704. https://doi.org/10.3791/2704. 26

Karanam G, Arumugam MK, Natesh, NS (2020) Anticancer effect of marine sponge associated Bacillus pumilus AMK1 derived dipeptide cyclo (-Pro-Tyr) in human liver cancer cell line through apoptosis and G2/M phase arrest. Int J Pept Res Ther 26:445-457. https://link.springer.com/article/10.1007/s10989019-09850-2

Kasala ER, Bodduluru LN, Madana RM, Athira KV, Gogoi R, Barua CC (2015) Chemopreventive and therapeutic potential of chrysin in cancer, mechanistic perspectives. Toxicol Lett 233:21425. https://doi.org/10.1016/j.toxlet.2015.01.008

Keil VC, Funke F, Zeug A, Schild D, Müller, M (2011) Ratiometric high-resolution imaging of JC-1 fuorescence reveals the subcellular heterogeneity of astrocytic mitochondria. Pfugers Arch 462:693708. https://doi.org/10.1007/s00424-011-1012-8

Koleva II, van Beek TA, Linssen JP, de Groot A (2002) Screening of plant extracts for antioxidant activity: a comparative study on three testing methods. Phytochem Anal 13:8-17. https://doi.org/10.1002/pca.611

Kumar S, Chandra P, Bajpai V, Singha A, Srivastava M, Mishra DK, et al (2015) Rapid qualitative and quantitative analysis of bioactive compounds from Phyllanthus amarus using LC/MS/MS techniques. Ind Crop Prod 69:143-152. https://pubag.nal.usda.gov/catalog/5428997

Kwon HJ, Kim LH, Ahn CH, Yang IH, Hong KO, Hong SD et al (2019) A new insight into the apoptotic effect of nitidine chloride targeting Checkpoint kinase 2 in human cervical cancer in vitro. J Clin Biochem Nutr 65:193-202. https://doi.org/10.3164/jcbn.19-28 
Litwin MS, Tan HJ (2017) The diagnosis and treatment of prostate cancer: A Review. JAMA 317:25322542. https://doi.org/10.1001/jama.2017.7248

Lu X, Yu H, Ma Q, Shen S, Das UN (2010) Linoleic acid suppresses colorectal cancer cell growth by inducing oxidant stress and mitochondrial dysfunction. Lipids Health

Dis 9:106. https://doi.org/10.1186/1476-511x-9-106

Meng H, Ni X, Yu H, Wang S, Shen S (2017) Effects of astaxanthin on oxidative stress induced by $\mathrm{Cu}^{2+}$ in prostate cells. J Zhejiang Univ Sci B 18:161-171. https://doi.org/10.1631/jzus.b1500296

Mikail HG, Akumka DD, Adamu M, Zaifada, AU (2019) Evaluation of phytochemical constituents and sedative-hypnotic activity of the methanol leaf extract of Ficus exasperata in mice. Vet World 12:830833. https://doi.org/10.14202/vetworld.2019.830-833

Mouho DG, Oliveira AP, Kodjo CG, Valentão P, Gil-Izquierdo A, Andrade PB, et al (2018) Chemical findings and in vitro biological studies to uphold the use of Ficus exasperata Vahl leaf and stem bark. Food Chem Toxicol 112:134-144. https://doi.org/10.1016/j.fct.2017.12.043

Nazıroğlu M. et al (2019) Albumin evokes Ca $\left({ }^{2+}\right)$-induced cell oxidative stress and apoptosis through TRPM2 channel in renal collecting duct cells reduced by curcumin. Sci Rep 9:

12403. https://doi.org/10.1038/s41598-019-54284-x

Ndeingang EC, Deeh PBD, Watcho P, Kamanyi A (2019) Phyllanthus muellerianus (Euphorbiaceae) restores ovarian functions in letrozole-induced polycystic ovarian syndrome in rats. Evid Based Complement Alternat Med 2019:2965821. https://doi.org/10.1155/2019/2965821

Nguyen VT (2021) Antiproliferative capacity of combined extracts from Paramignya trimera and Phyllanthus amarus against cancer cell lines. J Can Res Ther 17:471476. https://doi.org/10.4103/jcrt.jcrt_14_19

Oboh G, Akinyemi AJ, Osanyinlusi FR, Ademiluyi AO, Boligon AA, Athayde ML

(2014) Phenolic compounds from sandpaper (Ficus exasperata) leaf inhibits angiotensin 1 converting enzyme in high cholesterol diet fed rats. J Ethnopharmacol 157:119-25.

https://doi.org/10.1016/j.jep.2014.09.029

Olugbodi JO, Uzunuigbe EO, Oladipupo D, Ojo OA (2019) Effect of Glyphaea brevis twigs extract on cell viability, apoptosis induction and mitochondrial membrane potential in

TM3 Leydig cells. Andrologia 51:e13312. https://doi.org/10.1111/and.13312

Övey IS, Nazıroğlu, M (2015) Homocysteine and cytosolic GSH depletion induce apoptosis and oxidative toxicity through cytosolic calcium overload in the hippocampus of aged mice: involvement of TRPM2 and TRPV1 channels. Neuroscience 284:225-33. https://doi.org/10.1016/j.neuroscience.2014.09.078 
Özdemir ÜS, Nazıroğlu M, Senol N, Ghazizadeh, V (2016) Hypericum perforatum attenuates spinal cord injury-induced oxidative stress and apoptosis in the dorsal root ganglion of rats: Involvement of TRPM2 and TRPV1 channels. Mol Neurobiol 53:3540-3551. https://doi.org/10.1007/s12035-015-9292-1

Paul S, Patra D, Kundu, R (2019) Lignan enriched fraction (LRF) of Phyllanthus amarus promotes apoptotic cell death in human cervical cancer cells in vitro. Sci Rep

9:14950. https://doi.org/10.1038/s41598-019-51480-7

Rajeshkumar NV, Joy KL, Kuttan G, Ramsewak RS, Nair MG, Kuttan, R (2002) Antitumour and anticarcinogenic activity of Phyllanthus amarus extract. J Ethnopharmacol 81:1722. https://doi.org/10.1016/s0378-8741(01)00419-6

Rawla P (2019) Epidemiology of prostate cancer. World J Oncol 10:6389. https://doi.org/10.14740/wjon1191

Rezk BM, Haenen GR, van der Vijgh WJ, Bast A (2002) The antioxidant activity of phloretin: the disclosure of a new antioxidant pharmacophore in flavonoids. Biochem Biophys Res Commun 295:913. https://doi.org/10.1016/s0006-291x(02)00618-6

Romero-Garcia S, Prado-Garcia H (2019) Mitochondrial calcium: Transport and modulation of cellular processes in homeostasis and cancer (Review). Int J Oncol 54:1155-

1167. https://doi.org/10.3892/ijo.2019.4696

Rubnov S, Kashman Y, Rabinowitz R, Schlesinger M, Mechoulam R (2001) Suppressors of cancer cell proliferation from fig (Ficus carica) resin: isolation and structure elucidation. J Nat Prod 64:9936. https://doi.org/10.1021/np000592z

Schoots IG, Padhani AR (2020) Delivering clinical impacts of the MRI diagnostic pathway in prostate cancer diagnosis. Abdom Radiol 45:4012-4022. https://doi.org/10.1007/s00261-020-02547-x

Shiraishi N, Inai Y, Bi W, Nishikimi M (2005) Fragmentation and dimerization of copper-loaded prion protein by coppercatalysed oxidation. Biochem J 387:247-55. https://doi.org/10.1042/bj20041561

Simon H, Haj-Yehia A, Levi-Schaffer F (2000) Role of reactive oxygen species (ROS) in apoptosis induction. Apoptosis 5:415-418. https://doi.org/10.1023/a:1009616228304

Sinha BK, Trush MA, Kennedt KA, Edward G, Mimnaugh EG (1984) Enzymatic activation and binding of adriamycin to nuclear DNA. Cancer Res 44:2892-2896. https://pubmed.ncbi.nlm.nih.gov/6327028/

Su WC, Lin YF, Yu XP, Wang YX, Lin XD, Su QZ, et al (2017) Mitochondria-associated apoptosis in human melanoma cells induced by Cardanol Monoene from cashew nut shell liquid. J Agric Food Chem 65:5620-5631. https://doi.org/10.1021/acs.jafc.7b01381 
Tang YQ, Jaganath IB, Manikam R, Sekaran SD (2015) Phyllanthus spp. exerts anti-angiogenic and anti metastatic effects through inhibition on matrix metalloproteinase enzymes. Nutr Cancer 67:78395. https://doi.org/10.1080/01635581.2015.1040518

Tang YQ, Jaganath IB, Sekaran SD (2010) Phyllanthus spp. induces selective growth inhibition of PC-3 and MeWo human cancer cells through modulation of cell cycle and induction of apoptosis. PLoS One 5:e12644. https://doi.org/10.1371/journal.pone.0012644

Wang TH, Wang HS, Soong, Y.K (2000) Paclitaxel-induced cell death: where the cell cycle and apoptosis come together. Cancer 88:2619-28. https://doi.org/10.1002/1097-0142(20000601)88:11\%3C2619::aidcncr26\%3E3.0.co; $2-j$

Wisniewski T, Winiecki J, Makarewicz R, Zekanowska, E (2020) The effect of radiotherapy and hormone therapy on osteopontin concentrations in prostate cancer patients. J BUON 25:527530. https://www.jbuon.com/archive/25-1-527.pdf

Wu HY, Lin TK, Kuo HM, Huang YL, Liou CW, Wang PW, et al (2012) Phyllanthus urinaria induces apoptosis in human osteosarcoma 143B cells via activation of Fas/FasL- and mitochondria-mediated pathways. Evid Based Complement Alternat Med 2012:925824. https://pubmed.ncbi.nlm.nih.gov/22454688/

Xu Q Q, Ma X W, Dong X Y, Tao Z R Lu, L Z, Zou X T (2020) Effects of parental dietary linoleic acid on growth performance, antioxidant capacity, and lipid metabolism in domestic pigeons (Columba livia). Poult Sci 99:1471-1482. https://doi.org/10.1016/j.psj.2019.11.002

Yang M, Zhang X, Guo L, Liu X, Wu J, Zhu H (2021) Research progress for the clinical application of circulating tumor cells in prostate cancer diagnosis and treatment. Biomed Res Int 2021:6230826. https://doi.org/10.1155/2021/6230826

Zhang X, Huang J, Yu C, Xiang L, Li L, Shi D, et al (2020) Quercetin enhanced paclitaxel therapeutic effects towards PC-3 prostate cancer through ER stress induction and ROS production. Onco Targets Ther 13:513-523. https://doi.org/10.2147/ott.s228453

Zhu L, Chen L (2019) Progress in research on paclitaxel and tumor immunotherapy. Cell Mol Biol Lett 24:40. https://doi.org/10.1186/s11658-019-0164-y

\section{Figures}



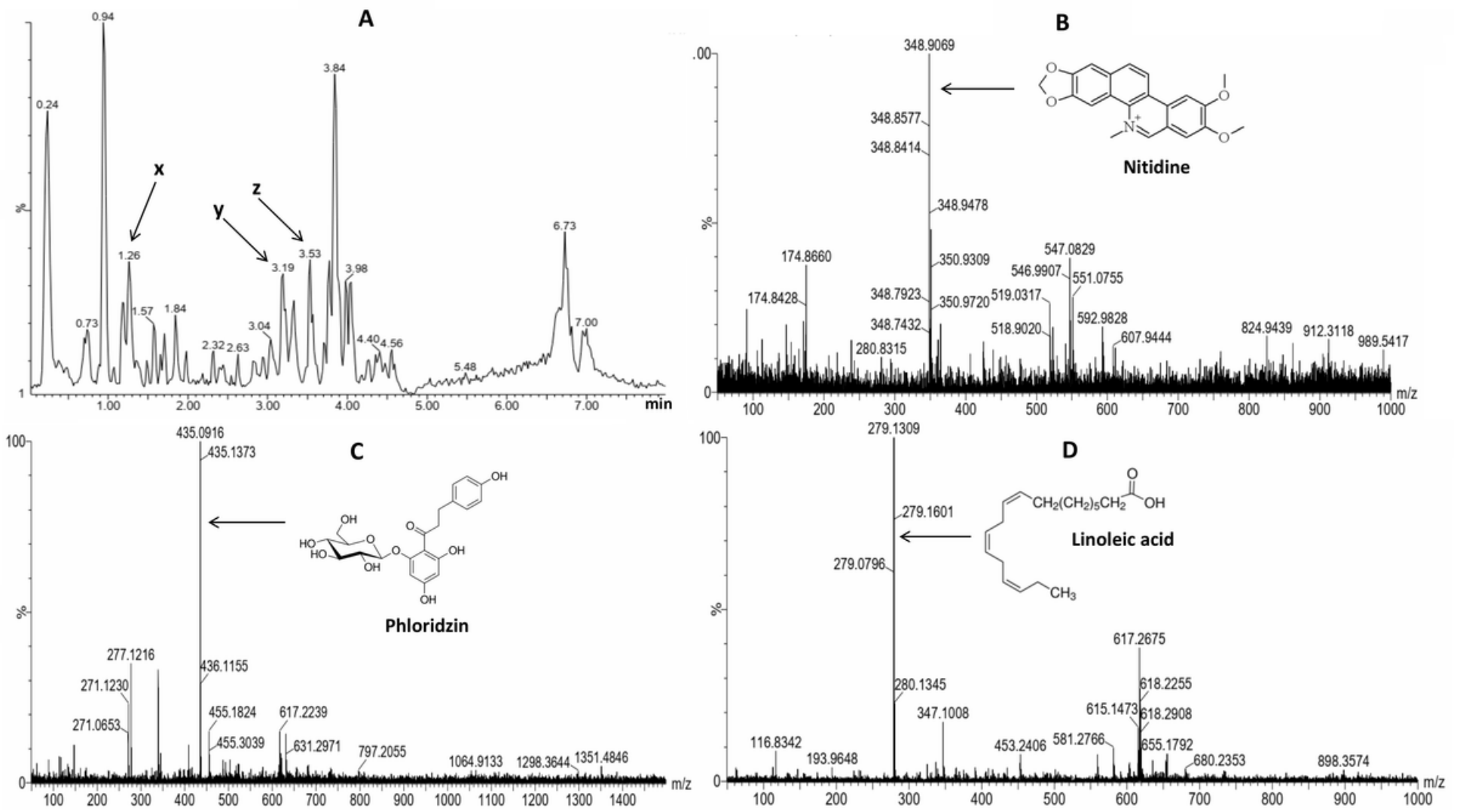

\section{Figure 1}

LC fingerprint of the methanolic extract of $P$. muellerianus. (A). B, C and D are MS spectra of compounds $\mathrm{x}$ (Nitidine), y (Phloridzin) and z (Linoleic acid), respectively. 

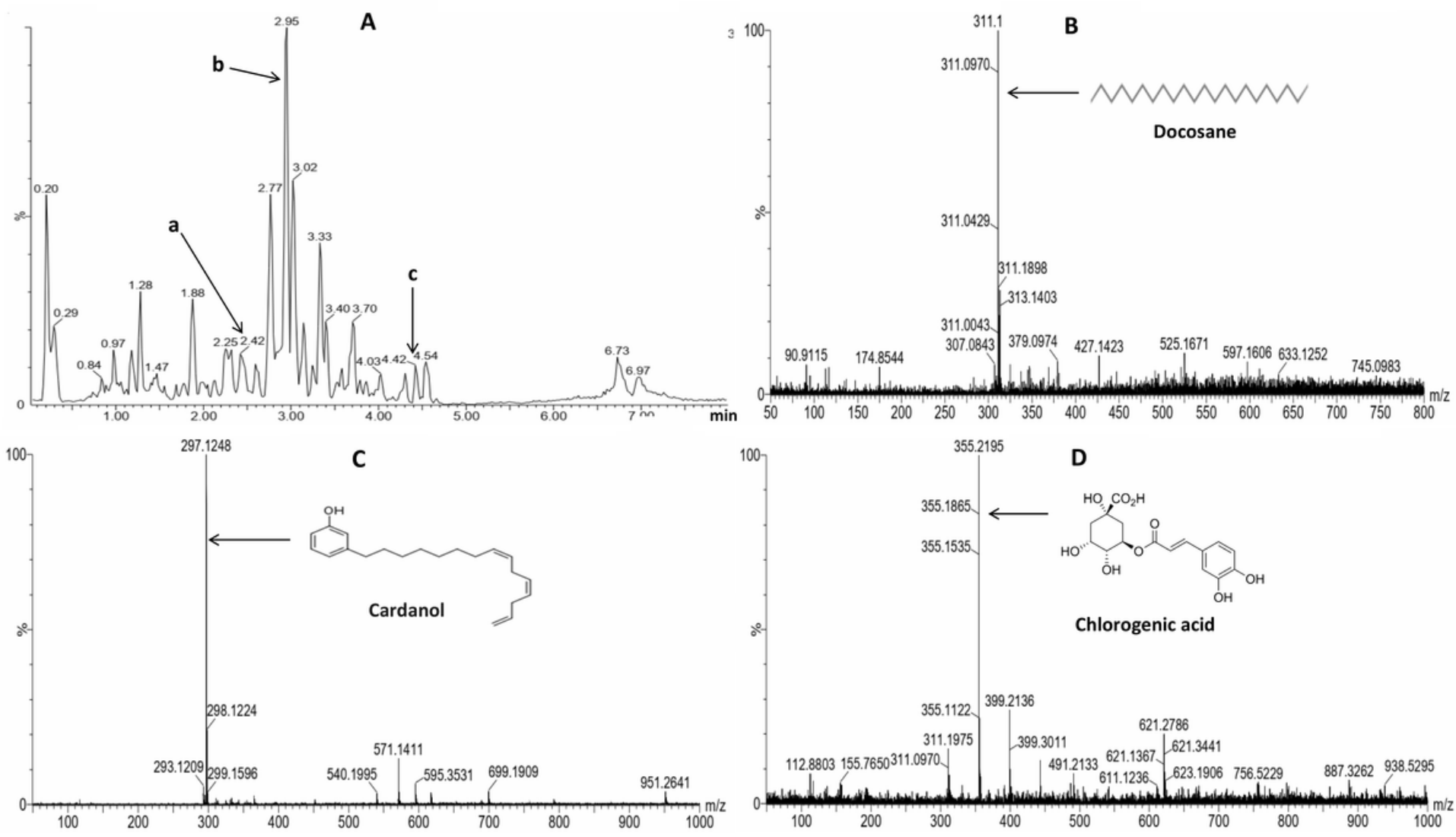

Figure 2

LC fingerprint of the methanolic extract of $F$. exasperata (A). B, C and D are MS spectra of compounds a (docosane), b (cardanol) and c (chlorogenic acid), respectively. 


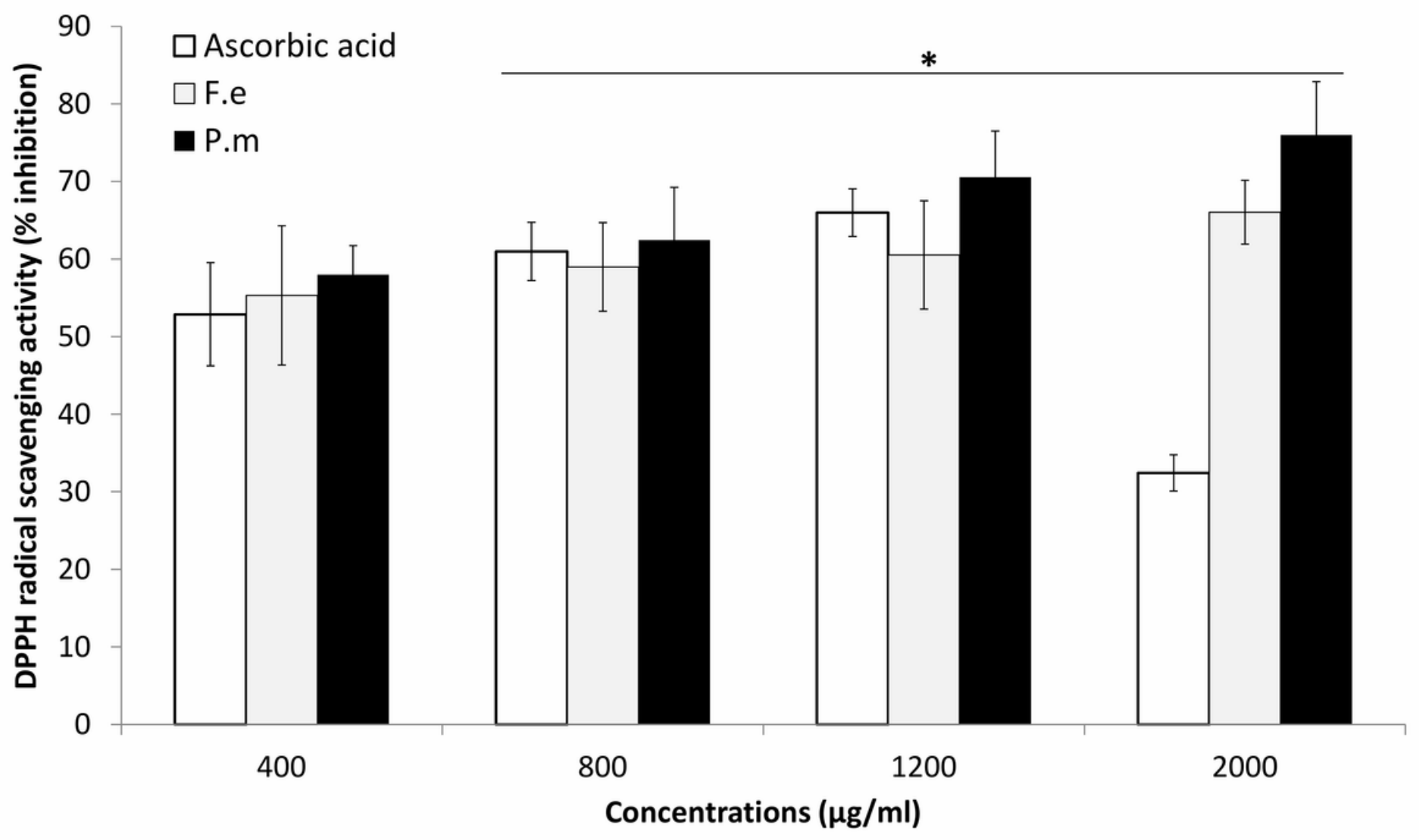

Figure 3

DPPH free radical scavenging activity of the methanolic extracts of $P$. muellerianus and $F$. exasperata. Number of replicate $=3 .{ }^{*} \mathrm{p}<0.001$ : compared to dose $400 \mu \mathrm{g} / \mathrm{ml}$. One-way ANOVA+Tukey HSD test. 


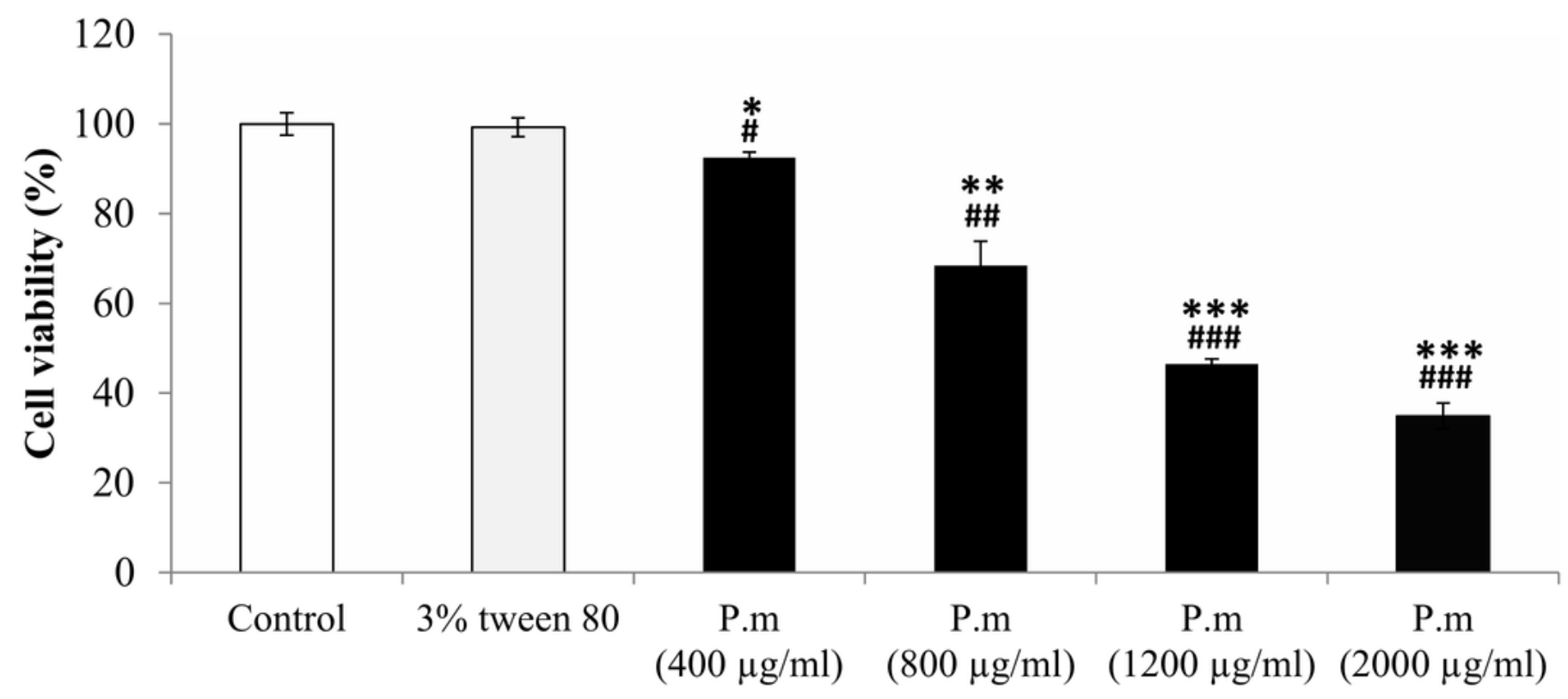

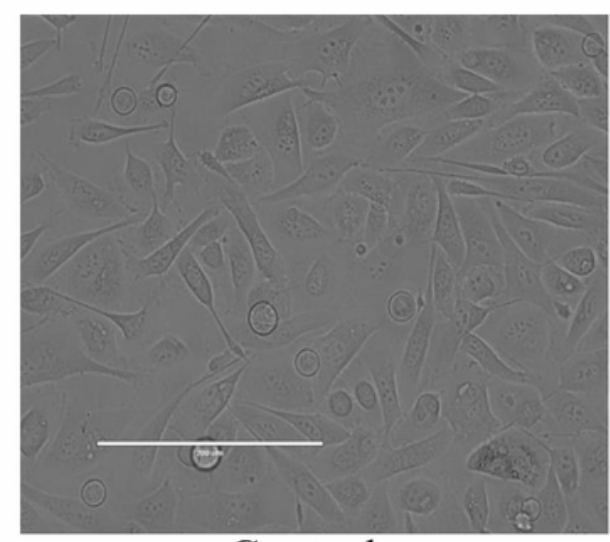

Control

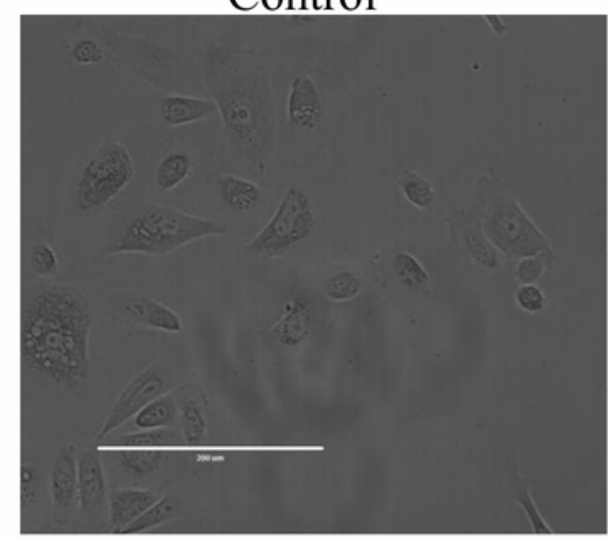

P.m $(800 \mu \mathrm{g} / \mathrm{ml})$

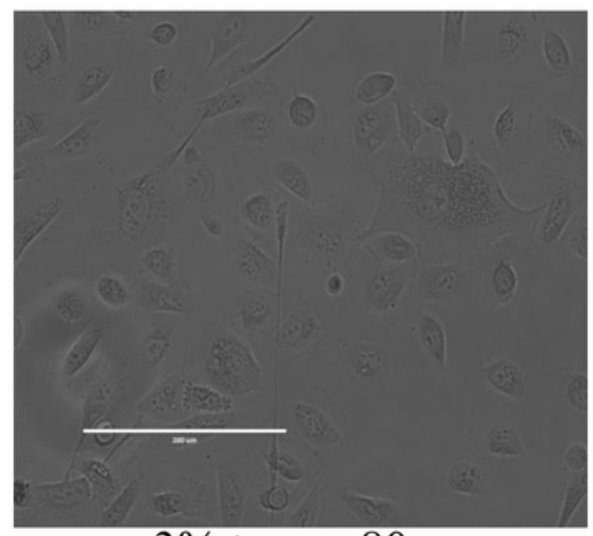

$3 \%$ tween 80

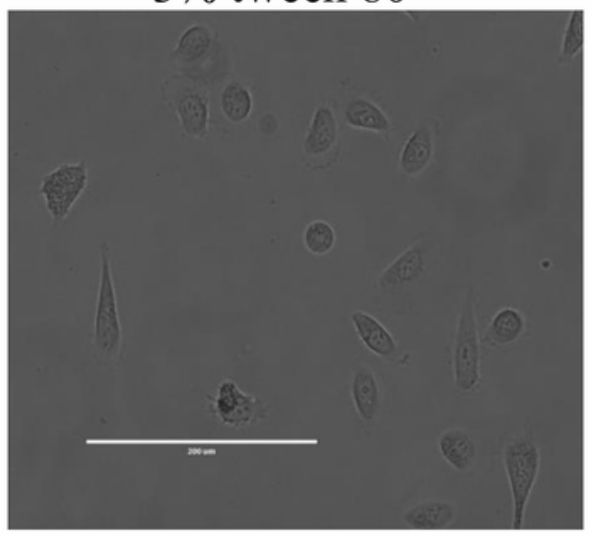

P.m $(1200 \mu \mathrm{g} / \mathrm{ml})$

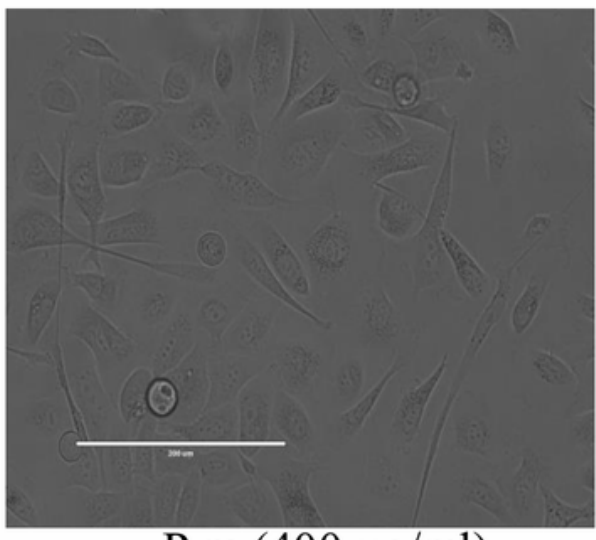

P.m $(400 \mu \mathrm{g} / \mathrm{ml})$

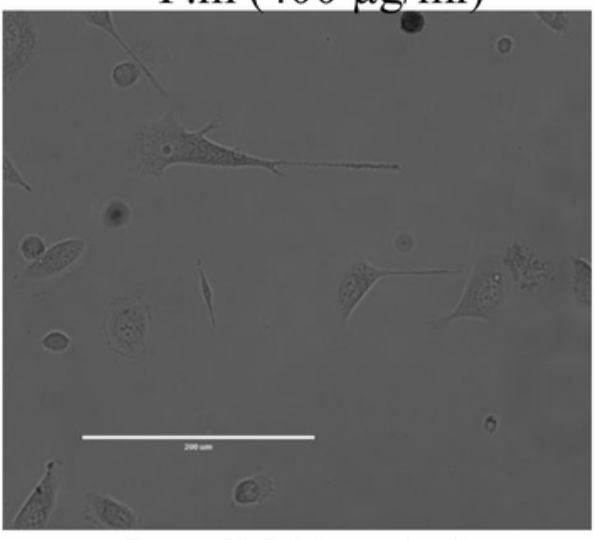

P.m $(2000 \mu \mathrm{g} / \mathrm{ml})$

\section{Figure 4}

P. muellerianus inhibited the viability of PC-3 cells. The cells were incubated for 24 hours with various concentrations $(400,800,1200$ and $2000 \mu \mathrm{g} / \mathrm{ml})$ of plant extract and cell viability was estimated as described under "Materials and methods" section. Experiments were performed in triplicate. Values are mean \pm SEM. ${ }^{*} p<0.05 ;{ }^{* \star} p<0.01 ;{ }^{* \star *} p<0.001$ : compared to control. $\# p<0.05 ; \# \# p<0.01 ; \# \# \# p<0.001$ : compared to tween 80. One-way ANOVA+Tukey HSD test. P.m: Phyllanthus muellerianus. Two moderate 
doses (infra $\mathrm{IC}_{50}: 800 \mu \mathrm{g} / \mathrm{ml}$ and supra $\mathrm{IC}_{50}: 1200 \mu \mathrm{g} / \mathrm{ml}$ ) were selected and used for further studies. Calibration bar $=200 \mu \mathrm{m}$.

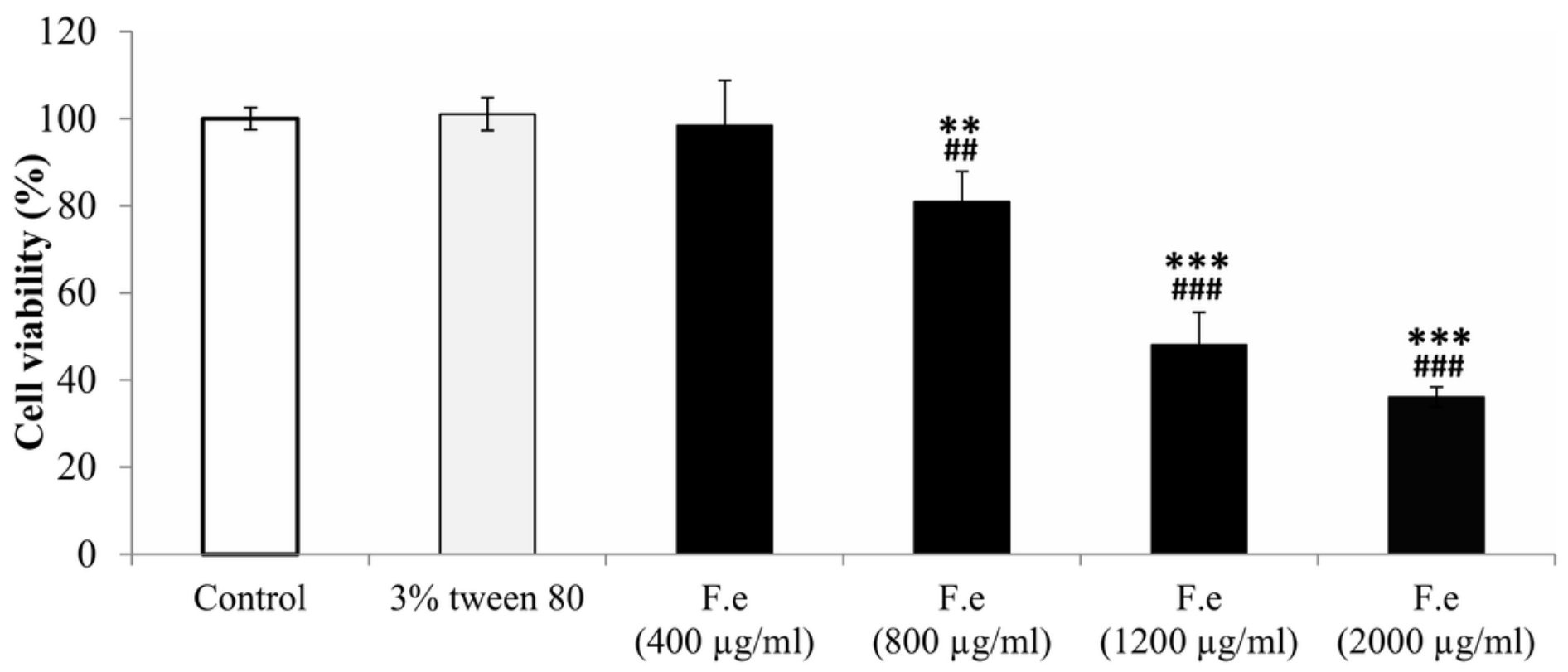

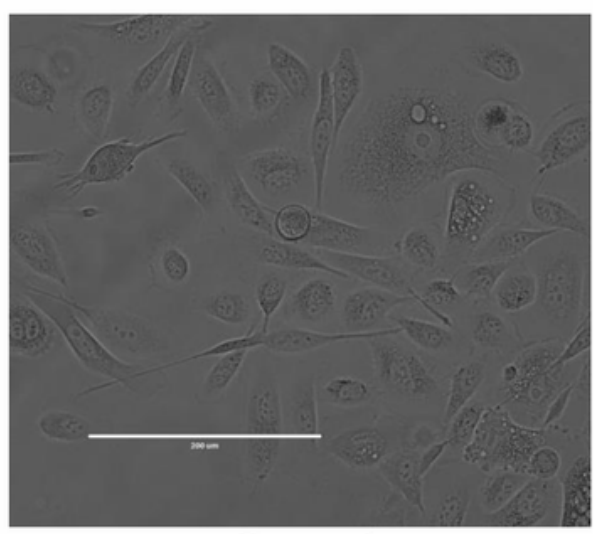

Control

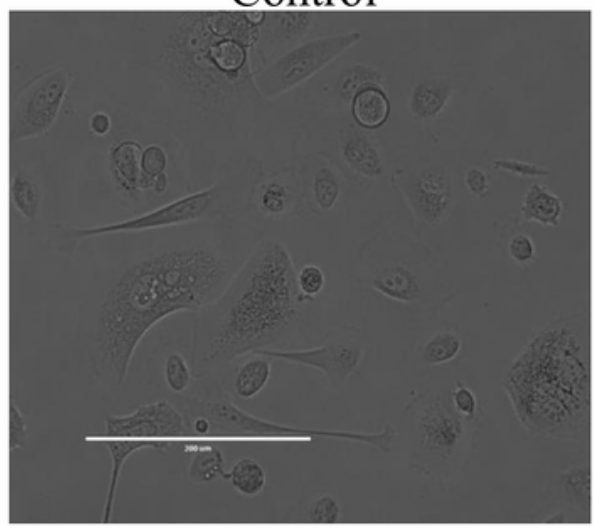

F.e $(800 \mu \mathrm{g} / \mathrm{ml})$

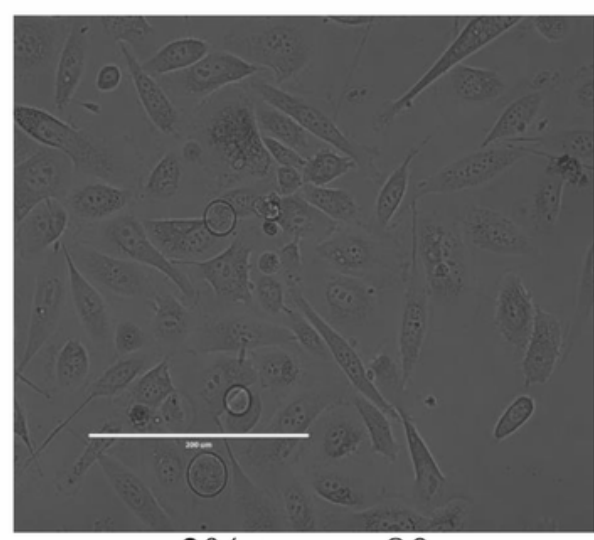

$3 \%$ tween 80

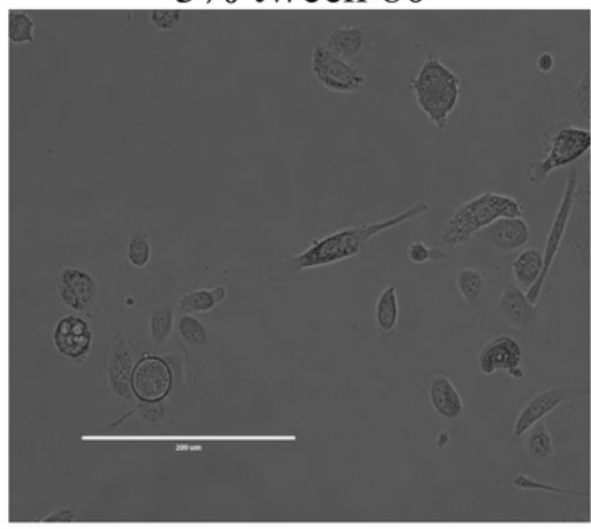

F.e $(1200 \mu \mathrm{g} / \mathrm{ml})$

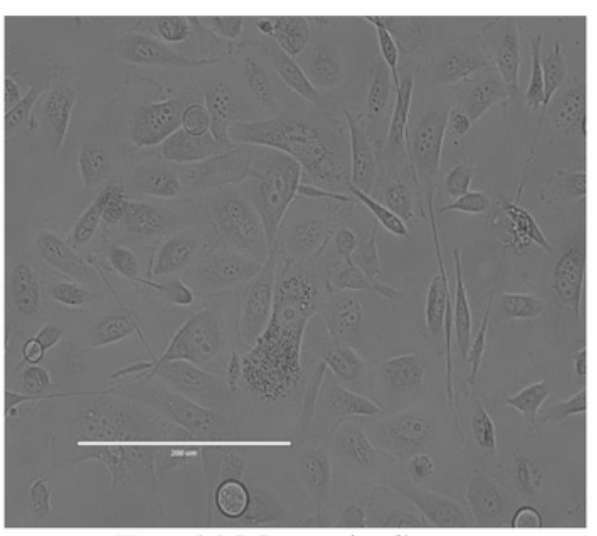

F.e $(400 \mu \mathrm{g} / \mathrm{ml})$

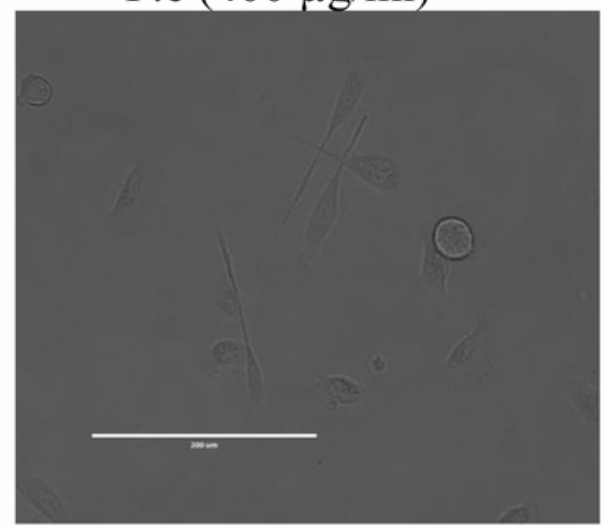

F.e $(2000 \mu \mathrm{g} / \mathrm{ml})$

\section{Figure 5}

F. exasperata inhibited the viability of PC-3 cells. The cells were incubated for 24 hours with various concentrations $(400,800,1200$ and $2000 \mu \mathrm{g} / \mathrm{ml})$ of plant extract and cell viability was estimated as 
described under "Materials and methods" section. Experiments were performed in triplicate. Values are mean \pm SEM. ${ }^{*} p<0.05 ;{ }^{\star \star} p<0.01 ;{ }^{* \star \star} p<0.001$ : compared to control. $\# p<0.05 ; \# \# p<0.01 ; \# \# \# p<0.001$ : compared to tween 80. One-way ANOVA+Tukey HSD test. F.e: Ficus exasperata; Two moderate doses (infra $\mathrm{IC}_{50}: 800 \mu \mathrm{g} / \mathrm{ml}$ and supra $\mathrm{IC}_{50}: 1200 \mu \mathrm{g} / \mathrm{ml}$ ) were selected and used for further studies. Calibration bar $=200 \mu \mathrm{m}$.
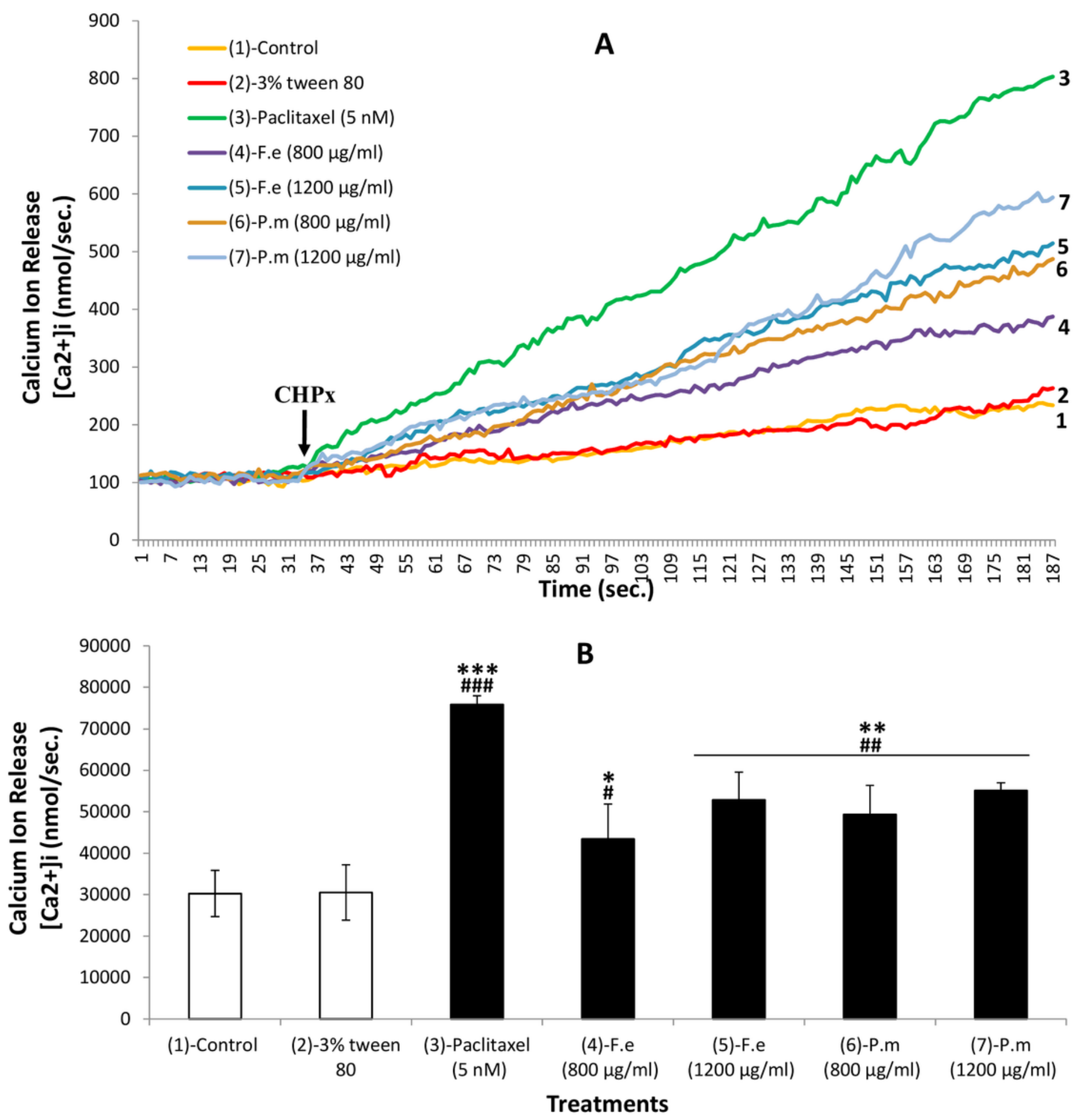

Figure 6 
Effects of $P$. muellerianus and $F$. exasperata on $\left[\mathrm{Ca}^{2+}\right]$ in the PC-3 cells (A and B). Values are mean $\pm \mathrm{SEM}$. After incubation (for 24 hours) with the vehicle, reference drug or plant extracts, the cells were exposed to $\mathrm{CHPx}$ to stimulate $\mathrm{Ca}^{2+}$ release, which was measured as described under "Materials and methods"

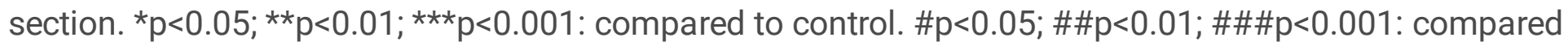
to tween 80. One-way ANOVA+Tukey HSD test. CHPx; Cumene hydroperoxide; F.e: Ficus exasperata; P.m: Phyllanthus muellerianus.
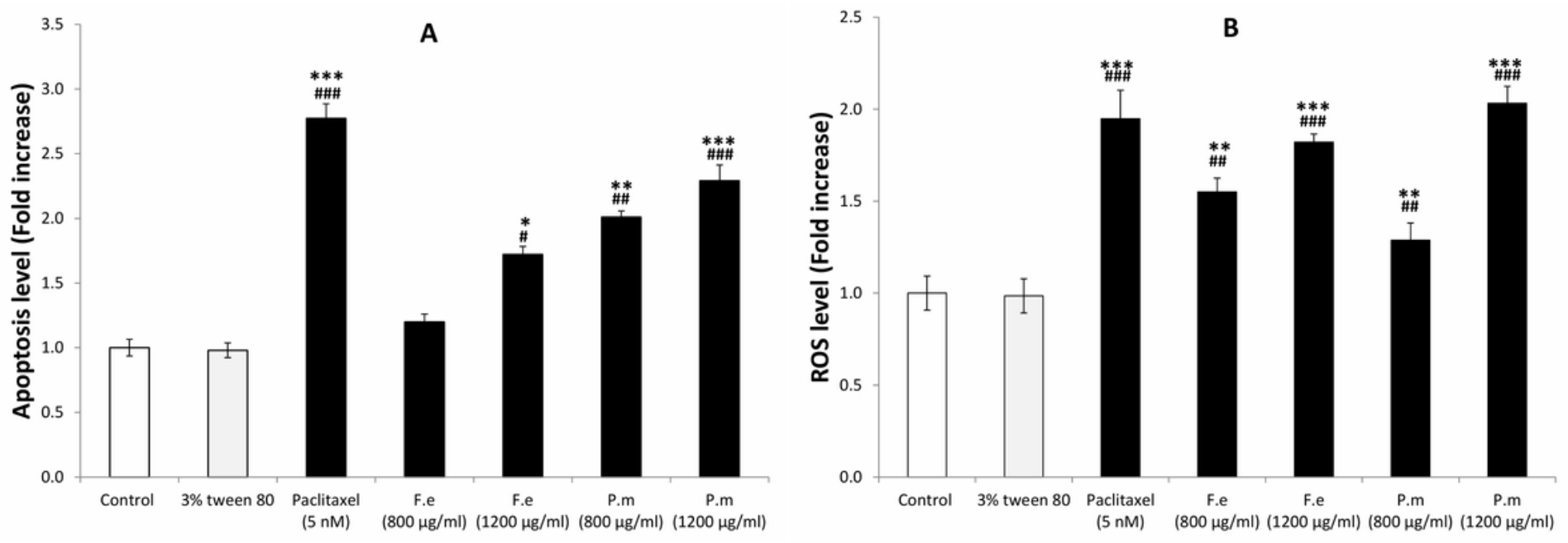

Figure 7

Effects of $P$. muellerianus and $F$. exasperata on apoptosis level (A) and ROS production (B) in the PC-3 cells. Each bar represents the mean \pm SEM. Apoptosis and ROS levels were determined as described under "Materials and methods" section. ${ }^{*} p<0.05 ;{ }^{* \star} p<0.01 ;{ }^{* \star *} p<0.001$ : compared to control. $\# p<0.05$; $\# \# p<0.01 ; \# \# \# p<0.001$ : compared to tween 80. One-way ANOVA+Tukey HSD test. F.e: Ficus exasperata; P.m: Phyllanthus muellerianus.
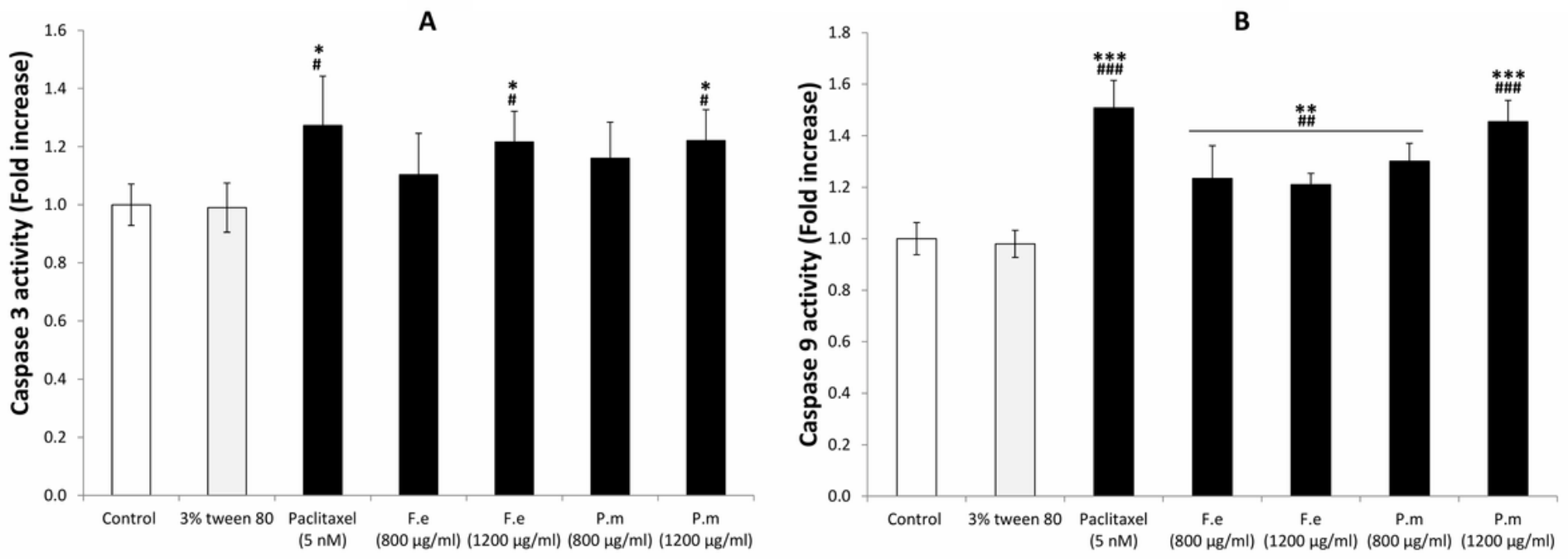

Figure 8 
Effects of $P$. muellerianus and $F$. exasperata on caspase $3(\mathrm{~A})$ and 9 (B) activities in the PC-3 cells. Each bar represents the mean \pm SEM. Caspases $3 / 9$ activities were determined as described under "Materials and methods" section. ${ }^{\star} p<0.05 ;{ }^{* \star} p<0.01 ;{ }^{* \star \star} p<0.001$ : compared to control. $\# p<0.05 ; \# \# p<0.01$; $\# \# \#$ <0.001: compared to tween 80. One-way ANOVA+Tukey HSD test. F.e: Ficus exasperata; P.m: Phyllanthus muellerianus.

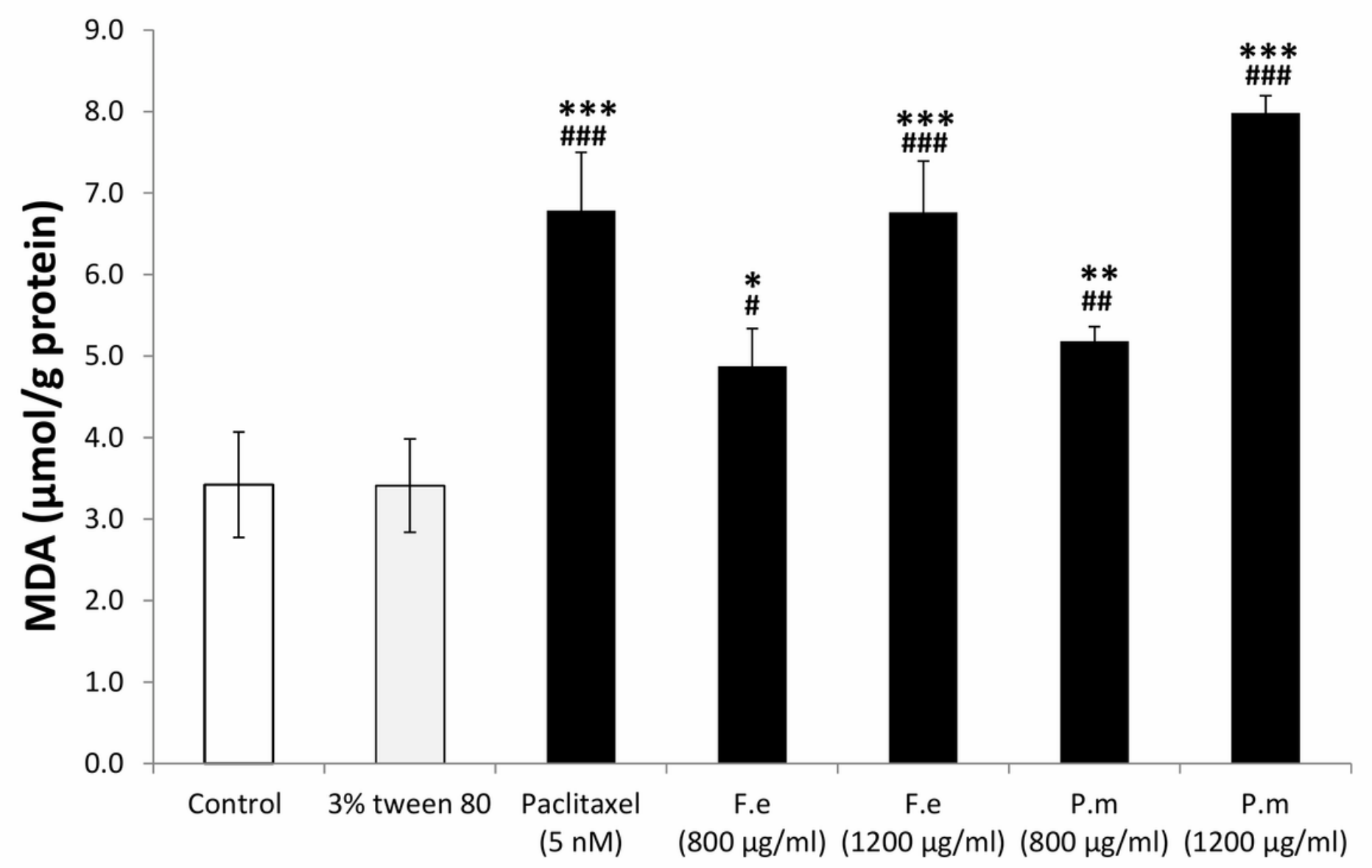

Figure 9

Effects of $P$. muellerianus and $F$. exasperata on MDA level in the PC-3 cells. Each bar represents the mean

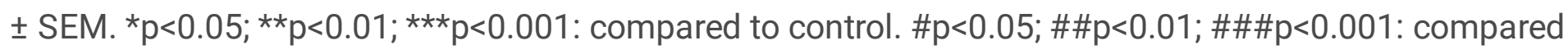
to tween 80. One-way ANOVA+Tukey HSD test. MDA: Malondialdehyde; F.e: Ficus exasperata; P.m:

Phyllanthus muellerianus. 

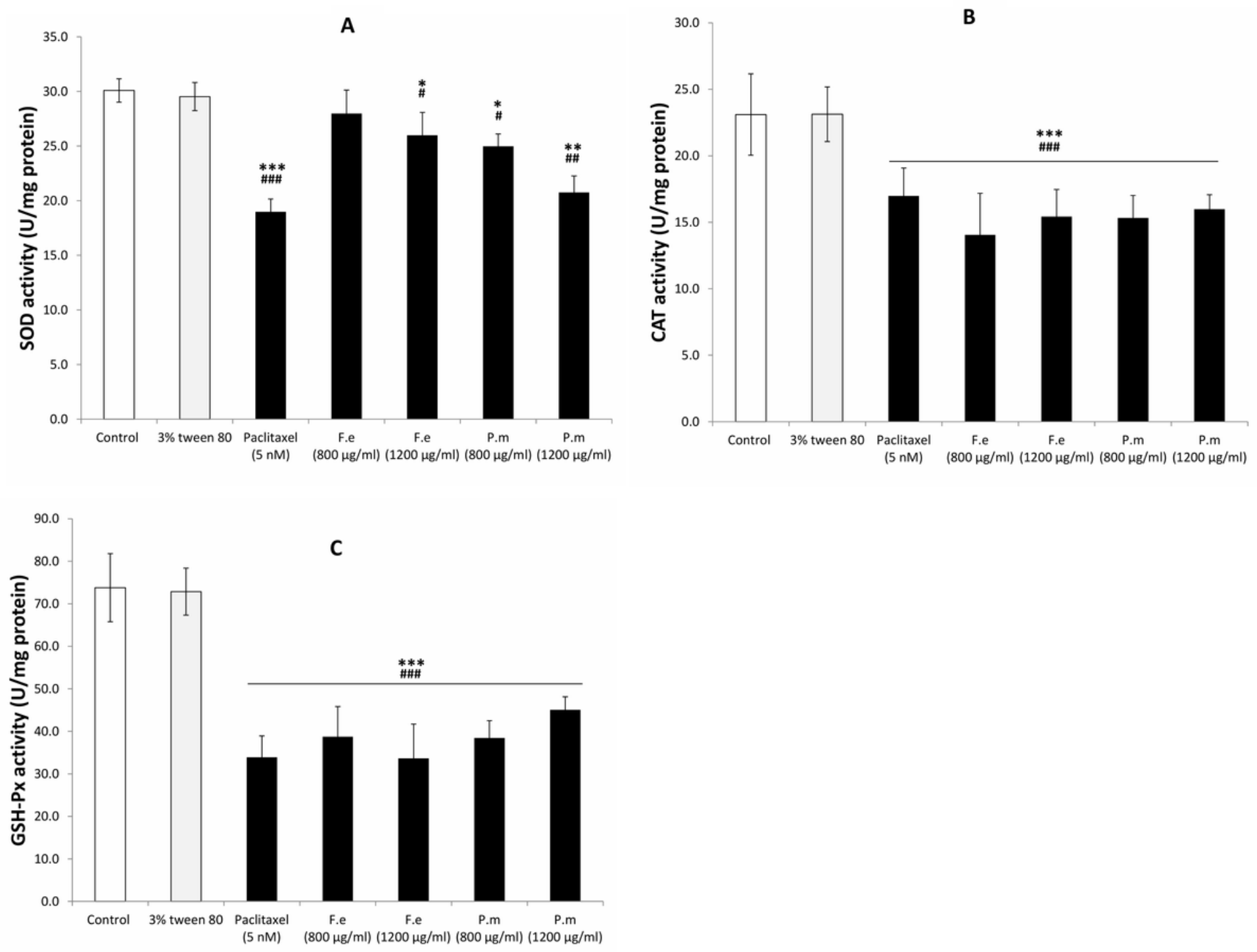

Figure 10

Effects of $P$. muellerianus and $F$. exasperata on the activities of SOD (A), catalase (B) and Glutathione (C) in the PC-3 cells. Each bar represents the mean \pm SEM. ${ }^{*} p<0.05 ;{ }^{* *} p<0.01 ;{ }^{* \star *} p<0.001$ : compared to control. \#p<0.05; \#\#p<0.01; \#\#\#p<0.001: compared to tween 80. One-way ANOVA+Tukey HSD test. SOD: Superoxide dismutase; CAT: Catalase; GSH-Px. Glutathione peroxidase; F.e: Ficus exasperata; P.m: Phyllanthus muellerianus. 
- Bax $\square$ Cytochrome C

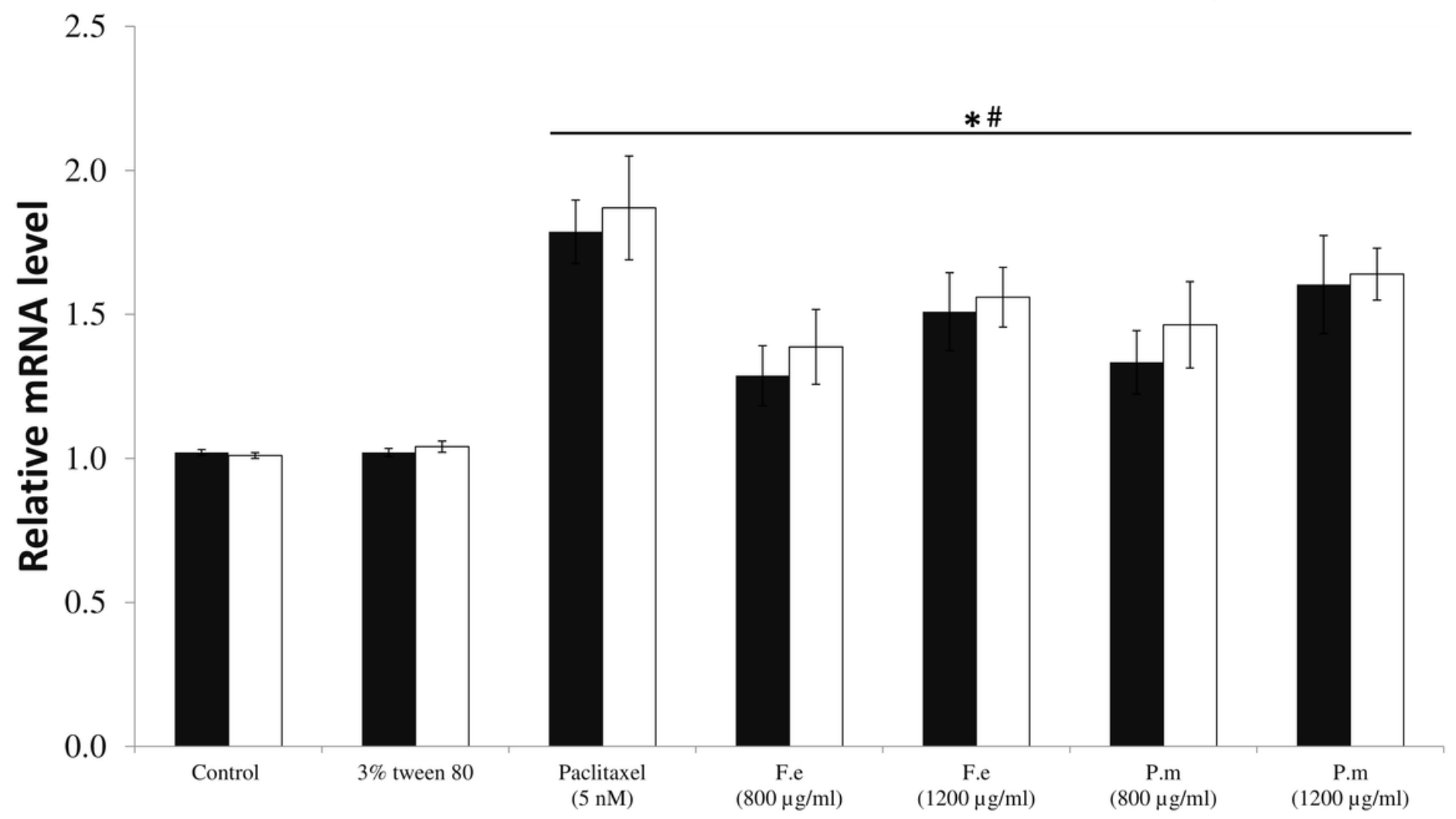

Figure 11

Effects of $F$. exasperata and P. muellerianus on mRNA expression of Bax and cytochrome $C$ in PC-3 cells. Gene expression levels represent the mRAN expression levels relative to control levels. Each bar represents the mean \pm SEM. ${ }^{*} p<0.05$ : compared to control. $\# p<0.05$ : compared to tween 80 . 


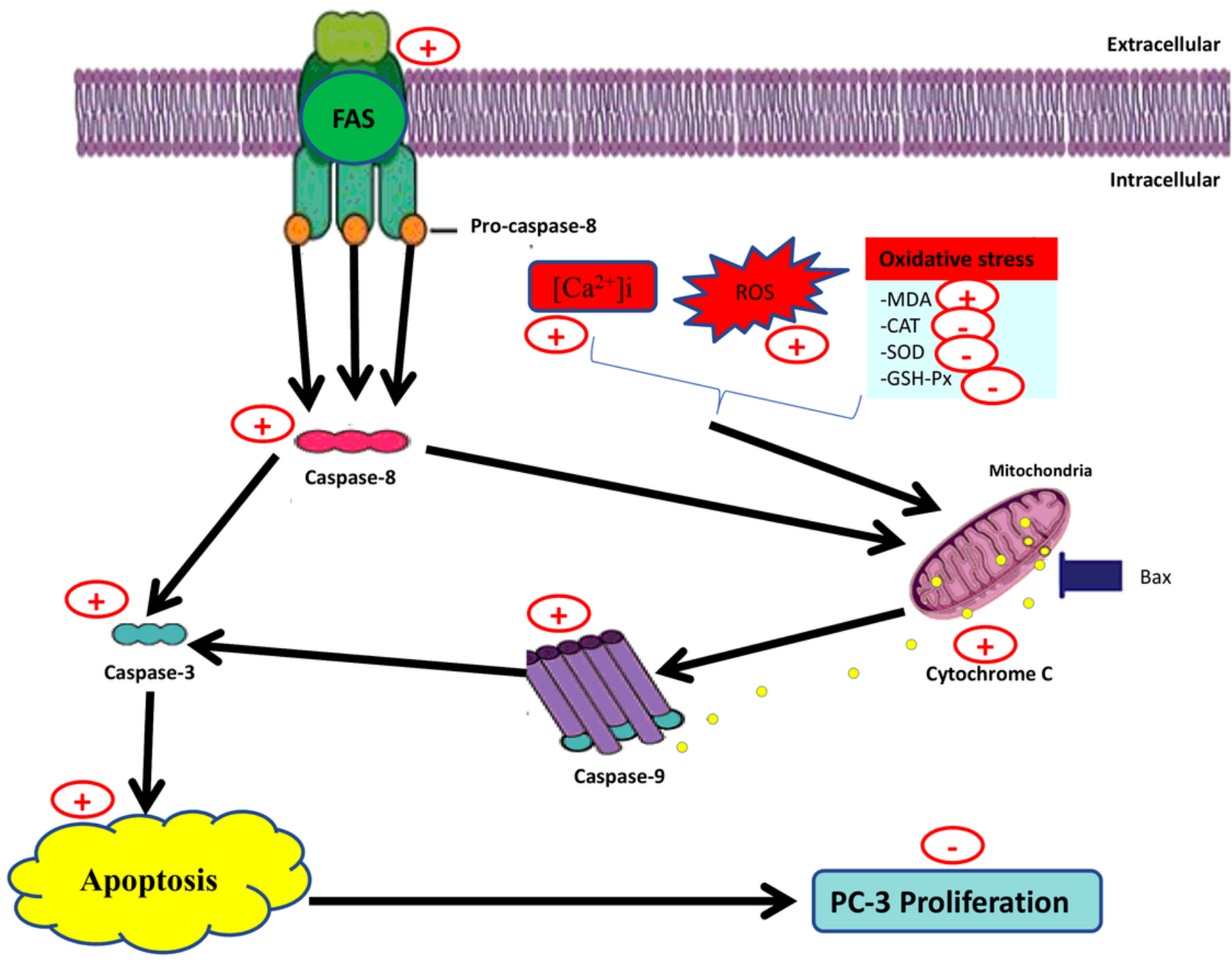

Figure 12

Proposed mechanism of action of $F$. exasperata and $P$. muellerianus on the proliferation of PC-3 cells.

FAS=APO-1: apoptosis antigen 1; ROS: reactive oxygen species; $\left[\mathrm{Ca}^{2+}\right]_{;}$: intracellular calcium concentration; MDA: Malondialdehyde; SOD: Superoxide dismutase; CAT: Catalase; GSHPX. Glutathione peroxidase; Bax: Bcl-2-associated X protein.

+ = stimulation; - = inhibition.

\section{Supplementary Files}

This is a list of supplementary files associated with this preprint. Click to download.

- SFile1.docx

- SFile2.docx

- SFile3.xIsx 